\title{
POLA SEBUTAN MONOFTONG BAHASA JERMAN OLEH PENUTUR BAHASA MELAYU
}

\section{(The Pronunciation Patterns of German Monophthongs among Malay Speakers)}

Yusnul'ain Yunus

ain581@uitm.edu.my

Akademi Pengajian Bahasa

Universiti Teknologi MARA.

Stefanie Pillai

stefanie@um.edu.my

Fakulti Bahasa dan Linguistik

Universiti Malaya.

Terbit dalam talian (published online): 7 Julai 2020

Sila rujuk: Yusnul'ain Yunus dan Stefanie Pillai. (2020). Pola Sebutan Monoftong Bahasa Jerman oleh Penutur Bahasa Melayu. Melayu: Jurnal Antarabangsa Dunia Melayu, 13(2), 223-252.

\begin{abstract}
Abstrak
Kajian ini tertumpu pada sebutan monoftong bahasa Jerman (B3) oleh penutur Melayu. Aspek yang dilihat ialah perbandingan cara sebutan monoftong B3 dengan sebutan monoftong bahasa Melayu Standard (B1) dan bahasa Inggeris (B2). Tujuannya untuk menilai jika terdapat persamaan dari segi sebutan monoftong yang hampir sama. Seramai 10 orang penutur perempuan berbangsa Melayu yang sedang mempelajari B3 telah membaca ayat yang mengandungi perkataan dengan monoftong sasaran dalam konteks /bVd/ dan /bVt/ bagi ketiga-tiga bahasa. Kesemua penutur juga mampu berbahasa Inggeris sebagai bahasa kedua. Berdasarkan model kekerapan forman, forman pertama (F1) dan kedua (F2) monoftong sasaran telah diukur. Durasi monoftong sasaran turut diukur. Taburan plot daripada monoftong yang setara antara tiga bahasa (B3, B1 \& B2) turut dinilai dalam konteks pemerolehan B3. Dapatan kajian menunjukkan bahawa penutur cenderung untuk menghasilkan monoftong yang setara dengan ciri-ciri akustik yang sama semasa menghasilkan
\end{abstract}

(C) Dewan Bahasa dan Pustaka. 2020. This work is licensed under the term of the Creative Commons Attribution (CC BY) (http://creative commons.org/licenses/by/4.0/)

ISSN 1675-6460 e-ISSN 2682-8049 
sebutan monoftong "baharu" B3 dengan vokal dari B1 atau B2 yang hampir. Hasil kajian ini dijangka mampu menyumbang kepada kajian pemerolehan B3.

Kata kunci: monoftong, pembelajaran bahasa ketiga, bahasa Jerman, bahasa Melayu, bahasa Inggeris

\begin{abstract}
This study investigates the pronunciation of German monophthongs (L3) by Malay speakers. It also compares the way the L3 monophthongs are produced with the monophthongs produced in Standard Malay (L1) and English (L2) to examine if there are any similarities in the way that equivalent vowels are produced. A total of 10 female Malay speakers who were learning German were recorded reading aloud carrier sentences containing the target vowels in $a / b V d /$ and $a / b V t /$ context in all three languages. All these speakers also speak English as a second language. Based on the formant frequency model, the first (L1) and second (L2) formants of the target monophthongs were measured. The duration of the vowels was also measured. Scatter plots of the vowels were also generated to enable comparison among similar sets of vowels within and among the three languages within the context of L3 acquisition. The findings suggest that speakers tend to produce equivalent vowels with similar acoustic properties, whilst tending to collapse "new" ones in the L3 to neighbouring $L 1$ or L2 vowels. The findings from this study contribute to the growing area of $L 3$ acquisition research.
\end{abstract}

Keywords: monophthong, L3 acquisition, German, Malay, English

\title{
PENDAHULUAN
}

Pendedahan terhadap perlunya penguasaan bahasa asing di Malaysia telah mula diketengahkah oleh pihak kerajaan sekitar tahun 1960-an. Penguasaan bahasa asing ini dianggap perlu bagi negara dalam menghadapi era globalisasi (Abdul Rashid et al., 2007). Kemasukan syarikat antarabangsa dan perkembangan teknologi turut menjadi pemangkin kepada kepentingan penguasaan bahasa asing, selain perkongsian kepakaran tertentu yang diperlukan dari negara terbabit. Di sekolah berasrama penuh terpilih, bahasa Jerman mula diajarkan kepada pelajar pada sekitar tahun 1990-an, sebagai salah satu pendidikan bahasa asing (Selke, 2013). Selain di peringkat sekolah, bahasa Jerman secara khususnya turut ditawarkan di beberapa institusi pengajian tinggi seperti di Universiti Malaya (UM), Universiti Putra Malaysia (UPM), Universiti Teknologi Mara (UiTM) dan beberapa lagi universiti awam dan swasta di Malaysia. 
Bahasa Jerman yang diajar di semua sekolah dan institusi pengajian tinggi di Malaysia ialah bahasa Jerman tinggi (Hochdeutsch) atau juga disebut bahasa Jerman standard. Di negara Jerman, secara dasarnya terdapat pelbagai jenis dialek yang digunakan. Penggunaan dialek terbabit berdasarkan kawasan geografi negara Jerman itu sendiri. Keadaan ini samalah seperti penggunaan dialek di negara-negara seperti Austria dan Switzerland yang masing-masing juga menggunakan bahasa Jerman sebagai bahasa kebangsaan mereka. Walau bagaimanapun, bahasa Jerman standard bagi kedua-dua negara terbabit adalah berbeza dengan bahasa Jerman standard di Jerman sendiri.

\section{PERMASALAHAN KAJIAN}

Menurut Gut (2010) disebabkan pelajar sudah memperoleh bahasa pertama dan bahasa kedua sebelum mempelajari bahasa ketiga, maka sistem produksi dan persepsi bahasa ketiga pelajar adalah lebih kompleks dan turut tidak menyamai produksi dan persepsi bahasa kedua mereka. Ciri fonetik bunyi termasuk vokal yang seakan-akan atau berbeza mempunyai implikasi terhadap pembelajaran bunyi tersebut dalam bahasa kedua atau bahasa ketiga (Bohn \& Flege, 1992; Gut, 2010). Seperti yang sedia dimaklumi, dalam sebutan sesuatu perkataan, bunyi huruf vokal memainkan peranan yang penting. Perbezaan sebutan huruf vokal panjang dan pendek dalam perkataan Stadt [Jtat] dan Staat [ $\left.\int \mathrm{ta}: t\right]$, kelainan bunyi huruf-huruf umlaut seperti

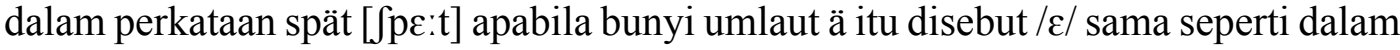
sebutan perkataan bet [bet] dalam bahasa Inggeris, selain perbezaan kualiti bunyi bagi sesetengah monoftong antara ketiga-tiga bahasa serta limitasi penggunaan bahasa Jerman di Malaysia adalah antara contoh yang menjadi kekangan kepada para pelajar untuk menyebut perkataan dalam bahasa Jerman secara natif. Berdasarkan kekangan yang timbul dapat dilihat bahawa kajian fonetik akustik bahasa Melayu masih kurang dilakukan. Malah kajian sedia ada hanya tertumpu pada B1 - B3 atau B1 - B2 sahaja. Selain itu, masih belum terdapat kajian sebutan monoftong BJS bagi penutur berbangsa Melayu secara akustik fonetik di Malaysia dan tidak terdapat kajian fonetik akustik bagi monoftong bahasa Melayu yang berlandaskan pengaruh silang linguistik di Malaysia, khususnya antara tiga bahasa (bahasa Melayu - bahasa Inggeris - bahasa Jerman).

Objektif kajian ini adalah untuk mengkaji pola sebutan monoftong bahasa Jerman sebagai B3 oleh pelajar Melayu dan juga membandingkan pola sebutan ini dengan pola produksi monoftong bahasa Melayu sebagai bahasa pertama (selepas ini B1) dan bahasa Inggeris sebagai bahasa kedua (selepas ini B2) pelajar Melayu. Berdasarkan objektif kajian, persoalan kajian ini adalah seperti yang berikut: (i) 
Apakah ciri fonetik monoftong B3 oleh penutur kajian berdasarkan analisis akustik? (ii) Apakah ciri fonetik monoftong B1 dan B2 oleh penutur kajian berdasarkan analisis akustik? (iii) Berdasarkan perbandingan pola fonetik monoftong dalam ketiga bahasa tersebut, sejauhmanakah pengaruh ciri-ciri monoftong B1 dan B2 terhadap sebutan monoftong B3?

Kajian ini diharapkan dapat menyumbang kepada pemahaman mengenai pola sebutan bahasa ketiga, iaitu bahasa Jerman berdasarkan kajian akustik. Selain itu, diharapkan juga dapat meningkatkan pengetahuan tentang pengaruh fonem vokal B1 dan B2 terhadap sebutan dalam B3, dan melihat bahasa yang lebih dominan dalam sebutan monoftong B3 tersebut.

\section{PERSEPSI DAN PRODUKSI BUNYI}

Persepsi sebutan oleh pendengar yang dibincangkan dalam kajian oleh Flege (1995), Guion et al. (2000) serta Aoyama et al. (2004) menekankan bahawa sekiranya pelajar bahasa kedua (B2) menganggap bunyi bahasa terbabit adalah sama dengan bahasa pertama (B1), maka bunyi B2 tersebut akan disebut dengan menyamakan bunyi yang terdekat daripada bahasa pertama (B1) mereka. Oleh itu, pelajar tidak membentuk kategori bunyi bahasa yang baharu walaupun dari sudut fonetik, kedua-dua bahasa (B1 dan B2) terbabit sebenarnya mempunyai bunyi yang berbeza. Misalnya, menurut Flege (1995) yang mengetengahkan Speech Learning Model (SLM), pembelajaran sebutan dalam B2 bergantung pada tahap persepsi kesamaan antara fonem dalam B1 dan B2. Fonem yang mempunyai perbezaan yang besar dikatakan akan dikuasai dengan lebih mudah berbanding fonem yang mempunyai banyak persamaan kerana ciri-ciri perbezaan akan dikenal pasti dan kategori baharu untuk fonem tersebut akan dibentuk (Flege, 1995). Sebaliknya, bunyi-bunyi B2, misalnya untuk bunyi vokal yang mempunyai ciri fonetik yang hampir sama dengan bunyi dalam B1 akan digabungkan dan menyebabkan bunyinya tidak akan menyamai bunyi natif B2 tersebut. Sebagai contoh, Flege (1995) mendapati bahawa penutur natif bahasa Sepanyol cenderung menyebut vokal bahasa Inggersi /æ/ seperti sebutan vokal bahasa Sepanyol /a/. Model SLM menjangkakan sekiranya hal ini berlaku, penutur tersebut akan merealisasikan vokal bahasa Inggeris /æ/ dengan menggunakan ciri-ciri /a/ dalam bahasa Sepanyol. Pelajar bahasa tahap awal dijangka akan lebih cenderung untuk mengasimilasi nilai forman vokal B2 kepada forman yang terdekat dalam B1 mereka (Escudero \& Williams 2011). Contohnya, pendengar bahasa Sepanyol Peru dalam kajian Escudero dan Williams (2011) menyerap vokal bahasa Belanda /y/ dalam vokal bahasa Sepanyol /i/ dan juga /u/. Malah, memandangkan terdapat lebih 
banyak monoftong dalam bahasa Belanda daripada bahasa Sepanyol, beberapa vokal bahasa Belanda diasimilasi dengan kategori vokal B1.

Walau bagaimanapun, kajian Munro (1993) mendapati, vokal yang berbeza dalam bahasa Arab dan bahasa Inggeris tidak dibezakan seperti ramalan SLM. Begitu juga, Yap, Wong dan Adi (2010), dalam kajian mengenai produksi vokal penutur bilingual Melayu-Inggeris mendapati bahawa penutur mereka sukar membezakan antara pasangan vokal bahasa Inggeris hadapan /I / yang merupakan vokal pendek serta /i/ yang merupakan vokal panjang. Hal ini mungkin disebabkan oleh tiada perbezaan kualiti dan kepanjangan vokal dalam bahasa Melayu. Oleh itu, boleh dijangkakan bahawa penutur akan menyatukan pasangan vokal ini. Penggabungan kualiti ini dilihat ketara dalam Stefanie, Zuraidah, Knowles dan Tang (2010).

Penemuan yang serupa telah dilaporkan oleh Iverson dan Evans (2007) yang mengkaji pengeluaran vokal bahasa Inggeris dalam kalangan penutur Perancis, Sepanyol, Jerman dan Norway. Penemuan mereka menunjukkan bahawa penutur bahasa Sepanyol dan Norway tidak menunjukkan bukti memperoleh vokal bahasa Inggeris /əv/ yang mempunyai lebih perbezaan dengan vokal terdekat dalam B1 mereka. Penutur B1 bahasa Jerman pula dapat menguasai sebutan bahasa Inggeris / aI/ yang mempunyai tahap kesamaan yang lebih tinggi antara dua bahasa ini. Iverson dan Evans (2007, p. 2842) membuat kesimpulan bahawa penutur daripada B1 mempelajari aspek baharu sistem vokal bahasa Inggeris secara berbeza, dan bukan hanya mengasimilasi vokal bahasa Inggeris kepada kategori yang sedia ada dalam B1 mereka.

\section{METODOLOGI}

\section{Penutur Kajian}

Data bagi kajian ini diambil daripada sepuluh orang pelajar perempuan dari sebuah universiti tempatan. Para pelajar terbabit merupakan siswazah Kursus Bahasa Jerman Tahap III berbangsa Melayu. Pemilihan kesemua penutur kajian ini berdasarkan soal selidik yang telah diedarkan pada peringkat awal kajian. Soal selidik ini untuk mengenal pasti penutur kajian yang benar-benar menepati kriteria yang telah ditetapkan, iaitu (1) berasal dari Selangor atau Johor; (2) tidak menggunakan dialek dalam perbualan harian serta; (3) mendapat keputusan MUET sekurang-kurangnya band tiga. Penetapan bagi kriteria (1) dan (2) adalah untuk memastikan penutur kajian menggunakan bahasa Melayu yang paling hampir dengan bahasa Melayu Standard. Pemilihan para pelajar daripada Kursus Bahasa Jerman Tahap III pula kerana para pelajar ini, secara puratanya, sudah mempelajari bahasa Jerman selama lebih 12 
bulan dan dianggap sudah mengetahui sedikit sebanyak tentang bahasa Jerman, walaupun masih berada pada tahap awal (beginner) pembelajaran bahasa tersebut.

\section{Senarai Perkataan}

Senarai perkataan bagi bahasa Jerman (B3) diambil daripada gabungan perkataan dalam kajian Ladefoged dan Ladefoged (2003) serta Mayr dan Escudero (2010). Perkataan yang ditanda bintang (*), diambil daripada kajian Mayr dan Escudero (2010) dan bukan perkataan (non words) yang bermakna, tetapi susunannya mengikut konvensi ejaan perkataan dalam BJS. Senarai perkataan bahasa Melayu (B1) pula telah diambil daripada kajian Yunisrina (2013) dan dirujuk juga dalam senarai daftar kata daripada Kamus Dewan (2005). Senarai perkataan bahasa Inggeris (B2) diambil secara keseluruhannya daripada Ladefoged (2001b). Kesemua perkataan sasaran yang menjadi data kajian kemudiannya diekstrak keluar daripada ayat apitan "Sila sebut ..... semula" (B1), "Please say .... again" (B2) dan "Ich habe ..... gesagt" (B3), setelah proses rakaman dilakukan. Jadual 1 memaparkan senarai perkataan $\mathrm{K} / \mathrm{V} / \mathrm{K}$ (konsonan/vokal/konsonan), iaitu huruf vokal tersebut didahului oleh konsonan /b/, $/ \mathrm{k} /, / \mathrm{p} /$ dan diikuti oleh konsonan plosif atau frikatif. Contohnya seperti perkataan

Jadual 1 Senarai perkataan B1, B2 dan B3 yang telah dirakamkan.

\begin{tabular}{|c|c|c|}
\hline Bahasa Jerman & $\begin{array}{l}\text { Bahasa } \\
\text { Melayu }\end{array}$ & Bahasa Inggeris \\
\hline$/ 1 /-$ bitten $=$ meminta & /i/ - pita & Ti: - bead = manik \\
\hline ii:/ - bieten = menawar & /e/ - petak & /I/ - bid = menawar \\
\hline /Y/ - Bütt* & $/ \partial /$ - peta & $\mid \varepsilon /-$ bed $=$ katil \\
\hline /y:/ - büht* & /a/ - pati & /æ/ - bad = jahat $/$ buruk \\
\hline$/ \mathrm{J} /$ - Butt $=$ sejenis ikan laut & $/ \mathrm{u} / \mathrm{-kutu}$ & $T_{\Lambda} /-$ bud $=$ putik \\
\hline /u:/ - buhten = mengejek /mencemuh & $/ \mathrm{o} /-$ kota & /a:/-bard = penyair \\
\hline le: $/$ - beten $=$ berdoa & & /3:/ - bird = burung \\
\hline |ø:/ - Böden = lantai (majmuk) & & $/ \mathrm{p} /-\operatorname{bod}(\mathrm{y})=$ tubuh badan \\
\hline /o:/ - Bot = saya /dia menawarkan & & to:/- bawd = penjodoh \\
\hline /ع:/ - bäten = meminta (kala lampau) & & $\begin{array}{l}\text { lv/- budd(ist) = penganut agama } \\
\text { Buddha }\end{array}$ \\
\hline $\mid \varepsilon /-$ Bett $=$ katil & & /u:/ - booed = mengejek / mencemuh \\
\hline
\end{tabular}


POLA SEBUTAN MONOFTONG BAHASA JERMAN OLEH PENUTUR BAHASA MELAYU

"pita", bunyi $[\mathrm{p} / \mathrm{s} / \mathrm{t}]$ mengikut susunan $\mathrm{K} / \mathrm{V} / \mathrm{K}$. Bunyi konsonan sengauan dan sisian dielakkan kerana kedua-duanya boleh mempengaruhi bunyi vokal tersebut.

\section{Kutipan Data}

Rakaman dilakukan hanya dalam satu konteks pertuturan, iaitu membaca secara kuat senarai perkataan daripada dua bahasa dalam ayat apitan (carrier sentence). Para penutur kajian diberikan masa sekurang-kurangnya lima hingga sepuluh minit bagi melatih sebutan masing-masing sebelum dipanggil secara individu untuk proses rakaman. Penutur dinasihatkan juga untuk membaca senarai perkataan dalam keadaan tenang dan bersahaja. Setiap perkataan diulang sebut sebanyak dua kali oleh penutur. Bagi enam fonem vokal B1 yang telah diambil daripada sepuluh orang penutur, sebanyak 120 data telah diambil kira. Bagi B3 pula, jumlah token yang diambil sebanyak 300, daripada 15 perkataan bahasa tersebut. Rakaman kajian telah dilakukan dalam studio kedap bunyi bagi meminimumkan gangguan bunyi asing menggunakan perisian Sony Sound Force versi 8.0 dengan kondenser mikrofon (condenser microphone) model Audio Technica. Data ini kemudiannya didigitalkan pada kadar $41 \mathrm{kHz}$ dengan resolusi 16-bit.

\section{Analisis Data}

Data yang telah dirakamkan dianalisis menggunakan perisian PRAAT versi 5.3.47 (Boersma \& Weenink, 2013). Vokal sasaran diasingkan dan diukur berdasarkan pemeriksaan visual, gelombang bunyi dan spektrogram. Forman pertama (F1) untuk ketinggian vokal dan forman kedua (F2) untuk dimensi depan/belakang akan diukur. Kedua-dua forman ini dianggap sebagai isyarat paling penting untuk persepsi vokal (Fry, 1979; Kent \& Read, 2002; Watt \& Tillotson, 2001). F1 dan F2 diukur menggunakan linear predictive coding (LPC) daripada perisian PRAAT. Ukuran diambil pada pertengahan vokal, iaitu apabila ia berada pada tahap yang paling stabil (lihat Adank, Smits \& Hout, 2004; Hawkins \& Midgley, 2005; Ladefoged, 2003; Watt \& Tillotson, 2001). Purata F1 dan F2 untuk setiap monoftong akan ditukar kepada skala Bark bagi membolehkan bunyi vokal tersebut diplot pada carta vokal F1-F2 (Zwicker \& Terhardt, 1980).

Durasi pula diukur dalam milisaat. Ukuran bermula daripada awal bunyi vokal sasaran yang dapat dilihat pada spektrogram, hingga kepada penghujung bunyi tersebut dan sebelum bunyi konsonan di sebelahnya bermula. Ukuran durasi dilakukan bagi membolehkan pengkaji melihat perbezaan antara pasangan vokal kontra. 


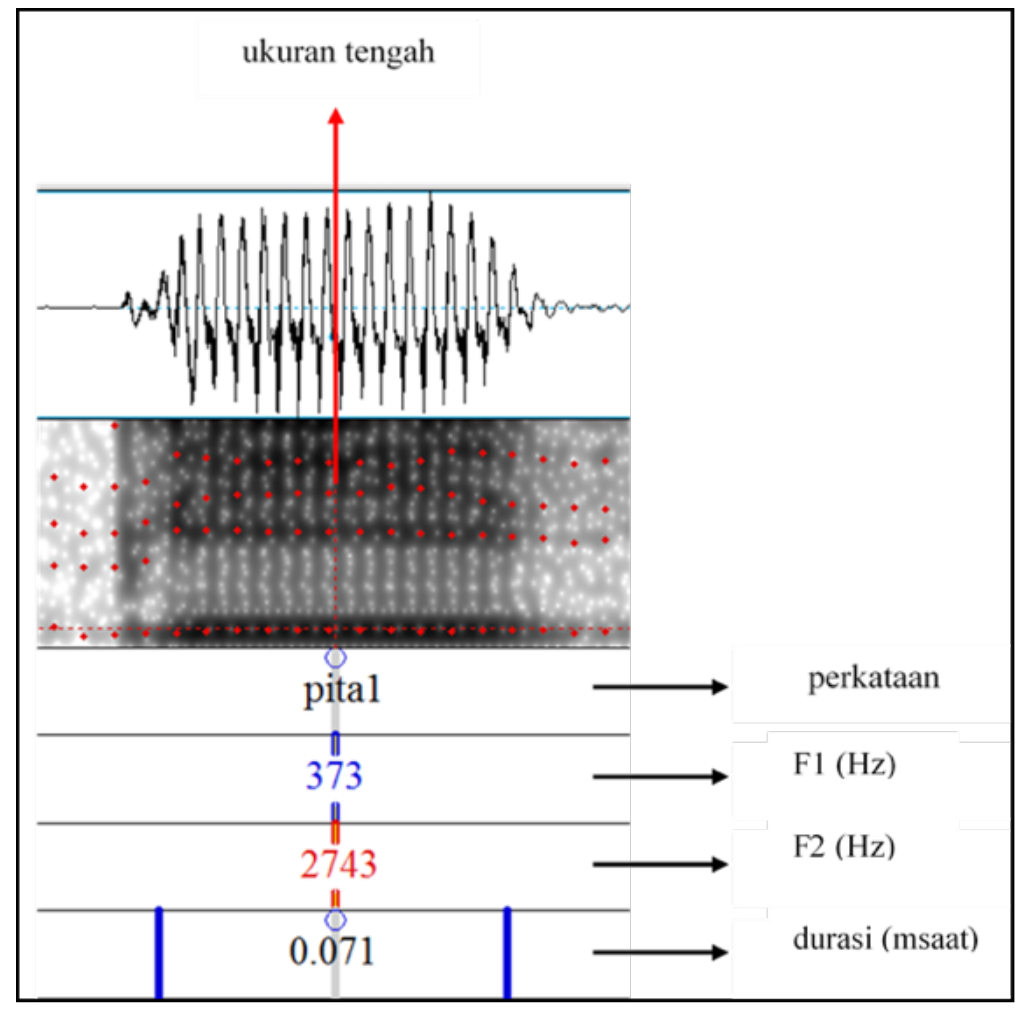

Rajah 1 Contoh ukuran perkataan sasaran "pita".

\section{DAPATAN KAJIAN}

\section{Vokal Bahasa Jerman}

Jadual 2 menunjukkan kesemua monoftong B3 yang dihasilkan oleh penutur, purata nilai F1 dan F2 mengikut ukuran hertz dan juga purata nilai forman F1 dan F2 bagi skala Bark. Rajah 2 pula memaparkan taburan vokal (vowel quadrilateral) bagi B3. Taburan kebanyakan fonem vokal B3 yang dipaparkan dalam Rajah di bawah, adalah selaras dengan deskripsi kedudukan fonem vokal dalam beberapa kajian terdahulu (Ladefoged \& Ladefoged, 2003; Lex \& Redecker, 2005; Rausch \& Rausch, 2002; Russ, 2010; Schunk, 2002).

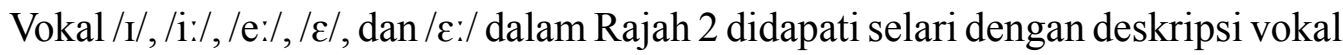
depan luas. Dari sudut kualiti, vokal /i:/ selaras dengan dapatan kajian terdahulu, iaitu vokal panjang /i:/ terhasil pada ruang vokal yang lebih tinggi berbanding /I/. 
POLA SEBUTAN MONOFTONG BAHASA JERMAN OLEH PENUTUR BAHASA MELAYU

Jadual 2 Purata F1 dan F2 monoftong bahasa Jerman.

\begin{tabular}{|c|c|c|c|c|c|c|}
\hline Vokal & $\begin{array}{c}\text { Purata F1 } \\
\text { dan SD } \\
\text { (Hz) }\end{array}$ & $\begin{array}{c}\text { Purata F2 } \\
\text { dan SD } \\
\text { (Hz) }\end{array}$ & $\begin{array}{c}\text { F1 } \\
\text { (Bark) }\end{array}$ & $\begin{array}{c}\text { F2 } \\
\text { (Bark) }\end{array}$ & $\begin{array}{c}\text { Purata } \\
\text { durasi dan } \\
\text { SD (msaat) }\end{array}$ & $\begin{array}{c}\text { ED } \\
\text { (Bark) }\end{array}$ \\
\hline i: & $\begin{array}{l}321 \\
(28.95)\end{array}$ & $\begin{array}{l}2626 \\
(384.58)\end{array}$ & 3.12 & 14.81 & $\begin{array}{l}221.10 \\
(84.04)\end{array}$ & 3.67 \\
\hline $\mathbf{I}$ & $\begin{array}{l}355 \\
(52.90)\end{array}$ & $\begin{array}{l}2586 \\
(308.04)\end{array}$ & 3.43 & 14.72 & $\begin{array}{l}81.25 \\
(16.11)\end{array}$ & 3.46 \\
\hline $\mathbf{y}$ & $\begin{array}{l}381 \\
(66.99)\end{array}$ & $\begin{array}{l}1710 \\
(376.77)\end{array}$ & 3.68 & 12.07 & $\begin{array}{l}178.20 \\
(57.28)\end{array}$ & 1.37 \\
\hline y: & $\begin{array}{l}397 \\
(70.16)\end{array}$ & $\begin{array}{l}1483 \\
(294.08)\end{array}$ & 3.82 & 11.12 & $\begin{array}{l}258.65 \\
(103.81)\end{array}$ & 1.25 \\
\hline e: & $\begin{array}{l}579 \\
(150.99)\end{array}$ & $\begin{array}{l}2354 \\
(290.85)\end{array}$ & 5.41 & 14.14 & $\begin{array}{l}159.55 \\
(48.43)\end{array}$ & 2.56 \\
\hline$\propto$ & $\begin{array}{l}439 \\
(72.03)\end{array}$ & $\begin{array}{l}1349 \\
(291.76)\end{array}$ & 4.19 & 10.46 & $\begin{array}{l}115.00 \\
(37.87)\end{array}$ & 1.37 \\
\hline $\mathbf{a}$ & $\begin{array}{l}864 \\
(84.96)\end{array}$ & $\begin{array}{l}1566 \\
(127.75)\end{array}$ & 7.60 & 11.49 & $\begin{array}{l}139.55 \\
(56.04)\end{array}$ & 2.63 \\
\hline a: & $\begin{array}{l}871 \\
(77.70)\end{array}$ & $\begin{array}{l}1492 \\
(147.52)\end{array}$ & 7.65 & 11.16 & $\begin{array}{l}248.40 \\
(89.94)\end{array}$ & 2.72 \\
\hline $\boldsymbol{\jmath}$ & $\begin{array}{l}638 \\
(127.66)\end{array}$ & $\begin{array}{l}1212 \\
(104.82)\end{array}$ & 5.90 & 9.77 & $\begin{array}{l}118.70 \\
(22.79)\end{array}$ & 2.07 \\
\hline o: & $\begin{array}{l}641 \\
(138.69)\end{array}$ & $\begin{array}{l}1048 \\
(143.32)\end{array}$ & 5.92 & 8.81 & $\begin{array}{l}220.65 \\
(87.04)\end{array}$ & 2.96 \\
\hline U & $\begin{array}{l}399 \\
(55.22)\end{array}$ & $\begin{array}{l}1149 \\
(173.76)\end{array}$ & 3.84 & 9.41 & $\begin{array}{l}131.80 \\
(44.38)\end{array}$ & 2.48 \\
\hline $\mathbf{u}:$ & $\begin{array}{l}377 \\
(37.54)\end{array}$ & $\begin{array}{l}1212 \\
(288.45)\end{array}$ & 3.63 & 9.77 & $\begin{array}{l}205.55 \\
(46.98)\end{array}$ & 2.29 \\
\hline б: & $\begin{array}{l}406 \\
(79.11)\end{array}$ & $\begin{array}{l}1175 \\
(185.62)\end{array}$ & 3.90 & 9.56 & $\begin{array}{l}251.40 \\
(62.11)\end{array}$ & 2.32 \\
\hline$\varepsilon:$ & $\begin{array}{l}635 \\
(168.47)\end{array}$ & $\begin{array}{l}2235 \\
(496.61)\end{array}$ & 5.87 & 13.81 & $\begin{array}{l}218.70 \\
(55.40)\end{array}$ & 2.37 \\
\hline$\varepsilon$ & $\begin{array}{l}726 \\
(89.95)\end{array}$ & $\begin{array}{l}2024 \\
(313.39)\end{array}$ & 6.59 & 13.18 & $\begin{array}{l}123.55 \\
(23.15)\end{array}$ & 2.25 \\
\hline Purata & & & & & $\begin{array}{l}178.14 \\
(55.69)\end{array}$ & 2.38 \\
\hline
\end{tabular}


Selain itu, vokal /I/ berada pada kedudukan yang lebih rendah dan lebih tengah (Ladefoged, 2001a; Russ, 2010; Tomaschek, Wieling, Arnold \& Baayen, 2013). Walau bagaimanapun, kedudukan empat vokal depan sempit, iaitu /y:/, /y/, /ø:/ dan /œ/ dalam Rajah 2, dilihat sedikit berbeza dengan deskripsinya kerana berada pada kedudukan yang lebih tengah, sementara vokal /ø:/ pula didapati bertindih dengan vokal /ひ/ oleh penutur kajian.

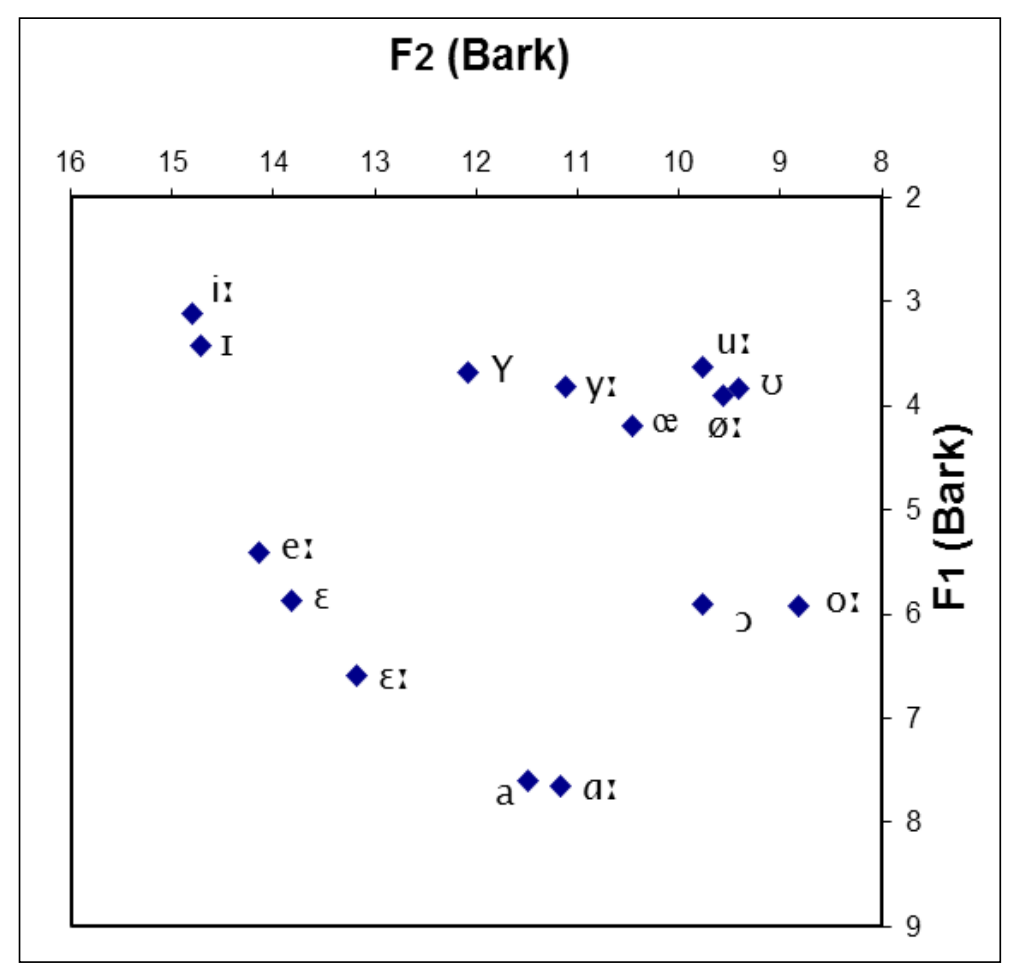

Rajah 2 Taburan monoftong bahasa Jerman oleh penutur kajian.

\section{Vokal Bahasa Melayu}

Jadual 3 menyenaraikan kesemua vokal monoftong B1 yang dihasilkan oleh penutur, purata nilai F1 dan F2 mengikut ukuran hertz dan juga purata nilai forman F1 dan F2 bagi skala Bark. 
POLA SEBUTAN MONOFTONG BAHASA JERMAN OLEH PENUTUR BAHASA MELAYU

Jadual 3 Purata monoftong F1 dan F2 bahasa Melayu oleh penutur kajian.

\begin{tabular}{|c|c|c|c|c|c|c|}
\hline Vokal & $\begin{array}{c}\text { Purata F1 } \\
\text { dan SD (Hz) }\end{array}$ & $\begin{array}{c}\text { Purata F2 } \\
\text { dan SD (Hz) }\end{array}$ & $\begin{array}{c}\text { F1 } \\
\text { (Bark) }\end{array}$ & $\begin{array}{c}\text { F2 } \\
\text { (Bark) }\end{array}$ & $\begin{array}{c}\text { Purata durasi } \\
\text { dan SD (msaat) }\end{array}$ & $\begin{array}{c}\text { ED } \\
\text { (Bark) }\end{array}$ \\
\hline $\mathbf{i}$ & $\begin{array}{c}368 \\
(35.68)\end{array}$ & $\begin{array}{c}2508 \\
(470.34)\end{array}$ & 3.55 & 14.53 & $\begin{array}{l}75.51 \\
(15.92)\end{array}$ & 3.00 \\
\hline e & $\begin{array}{c}514 \\
(82.41)\end{array}$ & $\begin{array}{c}2379 \\
(230.45) \\
\end{array}$ & 4.86 & 14.20 & $\begin{array}{c}83.07 \\
(11.04)\end{array}$ & 2.27 \\
\hline $\mathbf{a}$ & $\begin{array}{c}870 \\
(88.14)\end{array}$ & $\begin{array}{c}1640 \\
(214.06)\end{array}$ & 7.64 & 11.80 & $\begin{array}{l}105.65 \\
(16.51)\end{array}$ & 2.61 \\
\hline o & $\begin{array}{c}554 \\
(69.80) \\
\end{array}$ & $\begin{array}{c}1184 \\
(134.44)\end{array}$ & 5.20 & 9.61 & $\begin{array}{l}106.05 \\
(22.25)\end{array}$ & 2.34 \\
\hline $\mathbf{u}$ & $\begin{array}{c}393 \\
(48.26)\end{array}$ & $\begin{array}{c}1104 \\
(141.19)\end{array}$ & 3.79 & 9.15 & $\begin{array}{l}96.95 \\
(24.54)\end{array}$ & 3.06 \\
\hline$\partial^{*}$ & $\begin{array}{c}553 \\
(89.77)\end{array}$ & $\begin{array}{c}1786 \\
(186.67)\end{array}$ & 5.19 & 12.36 & $\begin{array}{l}71.20 \\
(15.68)\end{array}$ & 0.44 \\
\hline Purata & & & & & $\begin{array}{c}89.74 \\
(17.66)\end{array}$ & 2.65 \\
\hline
\end{tabular}

* Vokal tengah

F2 (Bark)

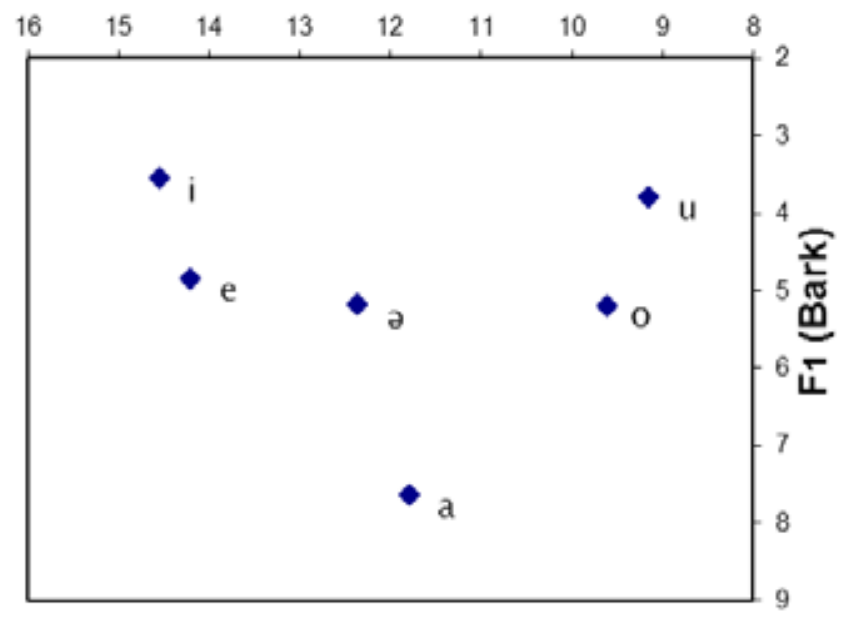

Rajah 3 Taburan monoftong bahasa Melayu. 
MELAYU: JURNAL ANTARABANGSA DUNIA MELAYU JILID 13 BIL. 2 JULAI 2020

Rajah 3 memaparkan taburan monoftong bahasa Melayu yang dihasilkan oleh penutur kajian. Seperti yang boleh dilihat dalam Rajah 3, kedudukan monoftong B1 adalah selaras dengan deskripsi vokal oleh pengkaji terdahulu (Abdullah, 2005; Asmah, 1988; Yunus, 1980).

\section{Vokal Bahasa Inggeris}

Jadual 4 menyenaraikan jumlah kesemua 11 monoftong bahasa Inggeris yang dihasilkan oleh penutur, purata nilai F1 dan F2 mengikut ukuran hertz dan juga purata nilai forman F1 dan F2 bagi skala Bark. Rajah 4 memaparkan taburan vokal bagi bahasa Inggeris.

Jadual 4 Purata fonem F1 dan F2 bahasa Inggeris oleh penutur kajian.

\begin{tabular}{|c|c|c|c|c|c|c|}
\hline Vokal & $\begin{array}{c}\text { Purata F1 } \\
\text { dan SD (Hz) }\end{array}$ & $\begin{array}{c}\text { Purata F2 } \\
\text { dan SD (Hz) }\end{array}$ & $\begin{array}{c}\text { F1 } \\
\text { (Bark) }\end{array}$ & $\begin{array}{c}\text { F2 } \\
\text { (Bark) }\end{array}$ & $\begin{array}{l}\text { Purata durasi } \\
\text { dan SD } \\
\text { (msaat) }\end{array}$ & $\begin{array}{c}\text { ED } \\
\text { (Bark) }\end{array}$ \\
\hline i: & $\begin{array}{l}352 \\
(50.39)\end{array}$ & $\begin{array}{l}2552 \\
(501.99)\end{array}$ & 3.41 & 14.64 & $\begin{array}{l}195.35 \\
(80.95)\end{array}$ & 3.53 \\
\hline I & $\begin{array}{l}344 \\
(29.30)\end{array}$ & $\begin{array}{l}2574 \\
(309.11)\end{array}$ & 3.33 & 14.69 & $\begin{array}{l}119.05 \\
(33.18)\end{array}$ & 3.61 \\
\hline$\varepsilon$ & $\begin{array}{l}678 \\
(114.70)\end{array}$ & $\begin{array}{l}2263 \\
(273.46)\end{array}$ & 6.22 & 13.89 & $\begin{array}{l}157.65 \\
(55.25)\end{array}$ & 2.29 \\
\hline $\mathfrak{x}$ & $\begin{array}{l}752 \\
(89.85)\end{array}$ & $\begin{array}{l}2077 \\
(285.80)\end{array}$ & 6.79 & 13.35 & $\begin{array}{l}178.75 \\
(58.54)\end{array}$ & 2.11 \\
\hline $\boldsymbol{\Lambda}$ & $\begin{array}{l}836 \\
(143.01)\end{array}$ & $\begin{array}{l}1645 \\
(182.83)\end{array}$ & 7.40 & 11.82 & $\begin{array}{l}143.35 \\
(45.51)\end{array}$ & 1.99 \\
\hline $\mathbf{a}:$ & $\begin{array}{l}844 \\
(83.03)\end{array}$ & $\begin{array}{l}1464 \\
(146.42)\end{array}$ & 7.46 & 11.04 & $\begin{array}{l}198.70 \\
(67.18)\end{array}$ & 2.16 \\
\hline p & $\begin{array}{l}593 \\
(122.93)\end{array}$ & $\begin{array}{l}1184 \\
(97.32)\end{array}$ & 5.53 & 9.61 & $\begin{array}{l}141.35 \\
(14.64)\end{array}$ & 2.13 \\
\hline
\end{tabular}


POLA SEBUTAN MONOFTONG BAHASA JERMAN OLEH PENUTUR BAHASA MELAYU

\begin{tabular}{|c|c|c|c|c|c|c|}
\hline Vokal & $\begin{array}{c}\text { Purata F1 } \\
\text { dan SD (Hz) }\end{array}$ & $\begin{array}{c}\text { Purata F2 } \\
\text { dan SD (Hz) }\end{array}$ & $\begin{array}{c}\text { F1 } \\
\text { (Bark) }\end{array}$ & $\begin{array}{c}\text { F2 } \\
\text { (Bark) }\end{array}$ & $\begin{array}{c}\text { Purata durasi } \\
\text { dan SD } \\
\text { (msaat) }\end{array}$ & $\begin{array}{c}\text { ED } \\
\text { (Bark) }\end{array}$ \\
\hline o: & $\begin{array}{l}728 \\
(93.06)\end{array}$ & $\begin{array}{l}1150 \\
(78.44)\end{array}$ & 6.60 & 9.42 & $\begin{array}{l}214.65 \\
(63.48)\end{array}$ & 2.61 \\
\hline $\boldsymbol{\sigma}$ & $\begin{array}{l}396 \\
(41.09)\end{array}$ & $\begin{array}{l}1211 \\
(151.63)\end{array}$ & 3.81 & 9.76 & $\begin{array}{l}91.95 \\
(17.63)\end{array}$ & 2.55 \\
\hline $\mathbf{u}:$ & $\begin{array}{l}404 \\
(56.98)\end{array}$ & $\begin{array}{l}1046 \\
(149.65)\end{array}$ & 3.88 & 8.80 & $\begin{array}{l}219.75 \\
(76.42)\end{array}$ & 3.32 \\
\hline$*_{3}:$ & $\begin{array}{l}550 \\
(60.16)\end{array}$ & $\begin{array}{l}1726 \\
(136.61)\end{array}$ & 5.17 & 12.14 & $\begin{array}{l}163.65 \\
(51.21)\end{array}$ & 0.47 \\
\hline Purata & & & & & $\begin{array}{l}165.84 \\
(51.27)\end{array}$ & 2.63 \\
\hline
\end{tabular}

* Vokal tengah

\section{F2 (Bark)}

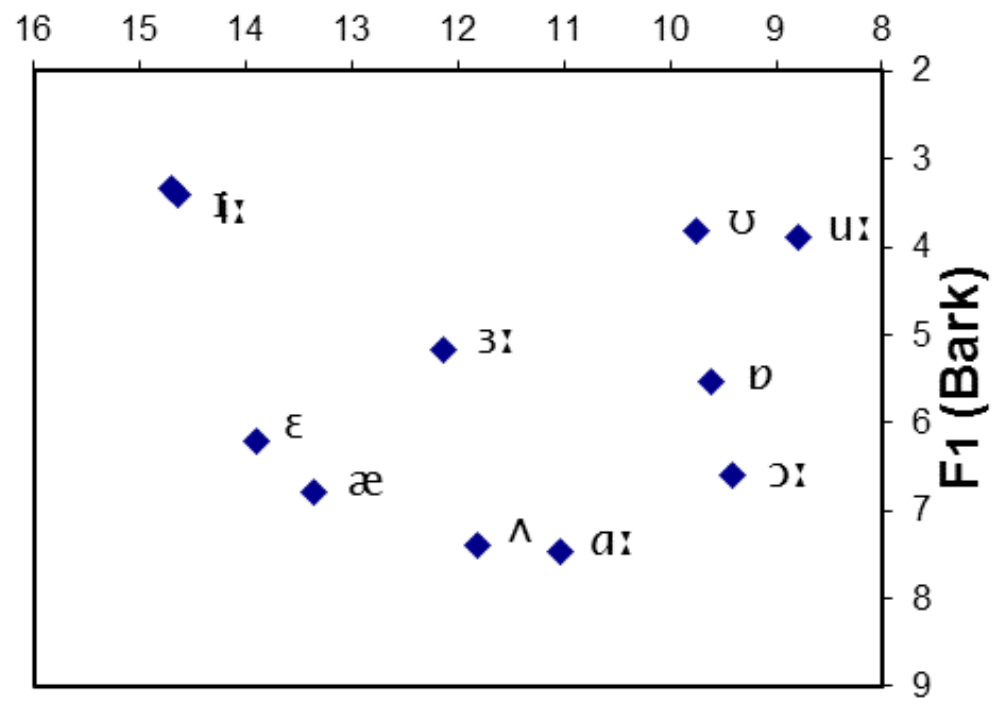

Rajah 4 Purata fonem F1 dan F2 bahasa Inggeris oleh penutur kajian. 
Didapati bahawa kedudukan vokal B2 adalah selaras dengan deskripsi vokal oleh pengkaji terdahulu (Ladefoged \& Ladefoged, 2003; Roach, 2000). Perbandingan antara kajian akustik bahasa Inggeris Malaysia (selepas ini MalE) yang dilakukan oleh Stefanie et al. (2010) serta Tan dan Low (2010) juga memaparkan kedudukan vokal yang hampir antara penutur kajian dengan kedua-dua kajian tersebut. Terdapat pertindihan atau jarak yang dekat antara pasangan vokal /I/ dan /i:/, / $/$ / dan /æ/, / / / dan /a:/, serta / / dan /u:/. Dengan itu, boleh dikatakan MalE mempunyai inventori vokal yang lebih kecil daripada sebutan bahasa Inggeris Standard variasi British.

\section{Perbandingan antara Vokal Bahasa Jerman, Bahasa Melayu dan Bahasa Inggeris Penutur Kajian}

Kesemua fonem B3 yang mempunyai kualiti yang serupa dengan B1 dan B2 akan dihuraikan selaras dengan hasil dapatan. Namun begitu, terdapat juga fonem B3 yang tidak mempunyai kualiti yang sama dengan B1 dan B2, namun turut dibandingkan kerana pertindihan dalam ruang vokal yang berlaku serta perbezaan yang tidak signifikan antara vokal didapati. Oleh yang demikian, pertindihan antara vokal /ø:/ dan / / / B3, turut dibandingkan dengan /u/ B1 dan B2 penutur kajian. Tiada perbandingan dilakukan terhadap vokal B3 /y:/, / $\varepsilon: /, / \mathrm{Y} /, / \varepsilon /$ dan /œ/ kerana tiada vokal yang serupa dari sudut kualiti dalam ruang vokal untuk dibandingkan, serta tiada persamaan yang signifikan antara kesemua vokal tersebut dengan mana-mana vokal dalam B1 mahupun B2.

Dapatan dalam bahagian ini akan dibincangkan secara berkelompok antara fonem vokal yang paling hampir bagi ketiga-tiga bahasa, iaitu daripada vokal /I/ B3 - /I/ B2 - /i/ B1 dan urutan bahasa yang sama bagi /i:/ - /i:/ - /i/ dan /e:/ - / ع/ - /e/.

Rajah 5 menunjukkan taburan vokal/I/ - /i/ bagi ketiga-tiga bahasa. Fonem/i/ B1, /I/ B2 dan /I/ B3 yang dihasilkan oleh penutur kajian adalah sama pada ketinggian (F1) dan keluasan lidah (F2). Ujian Friedman menunjukkan tiada perbezaan yang signifikan bagi $\mathrm{F} 1$ antara ketiga-tiga vokal ini, $\chi^{2}(2, \mathrm{~N}=20)=6.03, p=0.05$. Berdasarkan ujian yang sama bagi nilai $\mathrm{F} 2$ pula, juga didapati tiada perbezaan yang signifikan antara /I/ $-/ \mathrm{I} /-/ \mathrm{i} /$, iaitu $\chi^{2}(2, N=20)=0.7, p=0.70$. Ujian Friedman menunjukkan terdapat perbezaan durasi yang signifikan antara ketiga-tiganya pada $\chi^{2}(2, N=20)=20.8, p<0.05$. Namun begitu, ujian Wilcoxon Signed-ranks bagi /i/ $\mathrm{B} 1, / \mathrm{I} / \mathrm{B} 3$ pula menunjukkan, tidak terdapat perbezaan yang signifikan antara durasi keduanya, $Z=1.03, p=0.30, r=0.18$. Ini menjadikan sebutan $/ \mathrm{i} / \mathrm{B} 1 \mathrm{dan} / \mathrm{I} / \mathrm{B} 3$ telah disamakan dari semua aspek (kualiti dan durasi) oleh penutur kajian. 


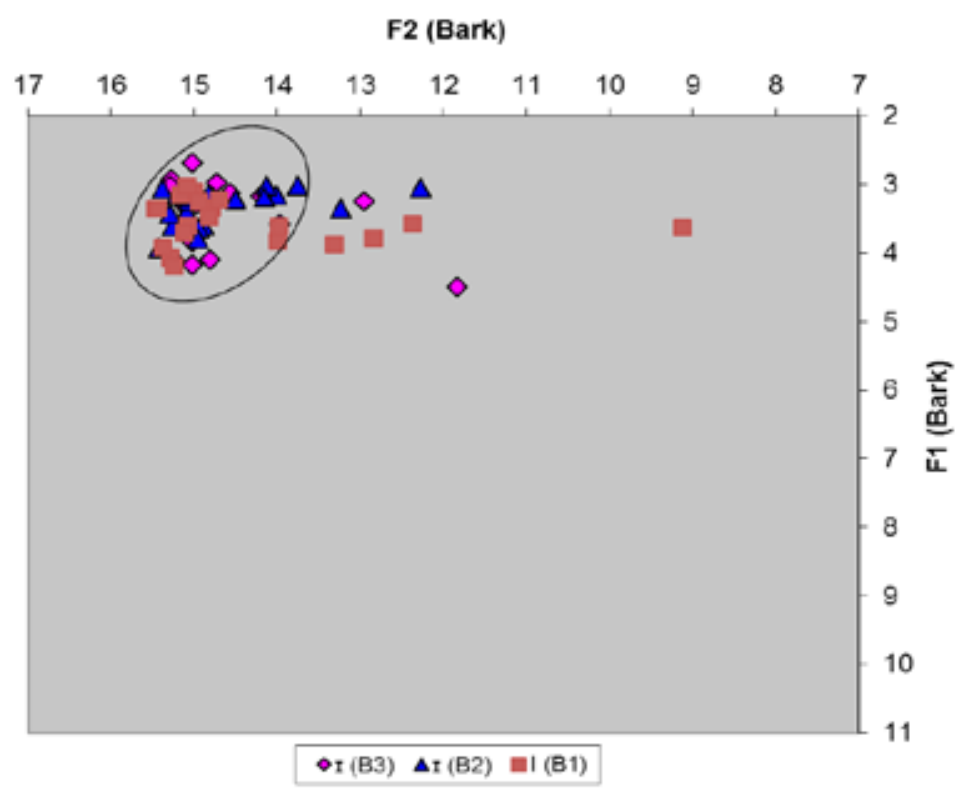

Rajah 5 Taburan vokal/i/ B1, /I/ B2 dan/I/ B3.

Rajah 6 memaparkan taburan vokal panjang /i:/ B2 dan B3 serta vokal /i/ B1. Ujian Friedman menunjukkan perbezaan yang signifikan bagi $F 1$ antara ketiga vokal ini pada kadar $\chi 2(2, \mathrm{~N}=20)=15.1, \mathrm{p}<0.05$. Walau bagaimanapun, ujian post hoc dan Wilcoxon Signed-ranks menunjukkan bahawa perbezaan F1 /i/ B1 dan /i:/ B2 adalah tidak signifikan, $Z=1.03, p=0.30, r=0.18$. Berdasarkan ujian Friedman bagi nilai F2 pula, didapati tiada perbezaan yang signifikan antara /i:/ (B3) - /i:/ (B2) - /i/ (B1), iaitu $\chi^{2}(2, N=20)=2.28, p=0.32$. Berpandukan ujian yang sama, terdapat perbezaan yang signifikan antara durasi /i:/ - /i:/ - /i/ pada $\chi^{2}(2, N=20)=$ $30.1, p<0.05$. Namun begitu, berdasarkan ujian Wilcoxon Signed-ranks dan ujian post hoc Tukey, tidak terdapat perbezaan durasi yang signifikan antara /i:/ B2 dan / i:/ B3, $Z=0.78, p=0.44, r=0.15$. Dapatan ini menunjukkan bahawa penutur kajian telah menyamakan /i/ B1 dan /i:/ B2 dari sudut kualiti, tetapi membezakan durasi / i:/ B2 dan menyamakannya dengan /i:/ B3. Data ini menyokong kajian Escudero dan Williams (2011) yang mengatakan pelajar bahasa tahap awal cenderung untuk mengasimilasi nilai forman vokal B2 kepada forman yang terdekat dalam B1 mereka. Daripada perbezaan F1 yang signifikan bagi fonem /i:/ B3 pula, dapatan adalah selaras dengan model pembelajaran B3 oleh Gut (2010) yang menyatakan penutur B3 sudah memiliki kemahiran linguistik daripada dua bahasa sebelumnya 


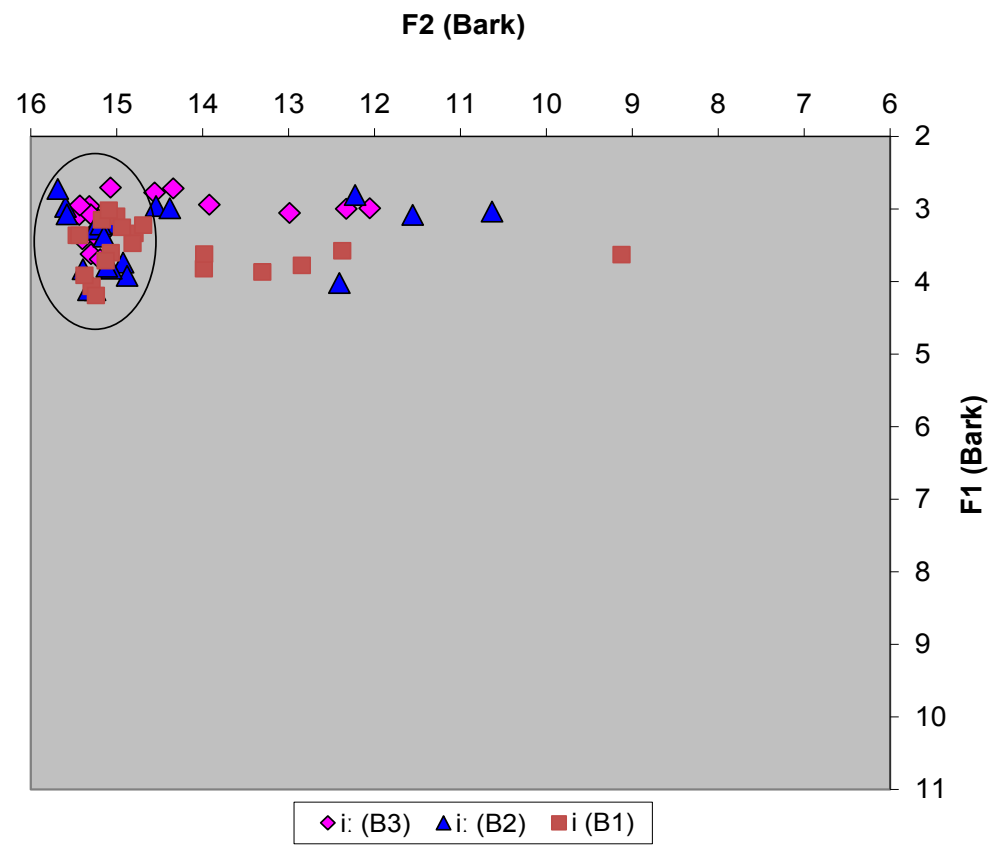

Rajah 6 Taburan vokal/i/ B1, /i:/ B2 dan /i:/ B3.

(B1 dan B2). Keadaan ini menjadikan B3 mereka lebih kompleks dan persepsi serta produksi $\mathrm{B} 3$ mereka berbeza dengan $\mathrm{B} 1$ mahupun $\mathrm{B} 2$.

Jadual 5 memaparkan purata F1, F2 dan durasi B1, B2 dan B3 bagi memudahkan perbandingan.

Jadual 5 Purata vokal /i/ bagi B1, B2 dan B3.

\begin{tabular}{|l|l|l|l|l|l|}
\hline Bahasa & $\begin{array}{l}\text { Purata F1 dan } \\
\text { SD (Hz) }\end{array}$ & $\begin{array}{c}\text { Purata F2 dan } \\
\text { SD (Hz) }\end{array}$ & F1 (Bark) & F2 (Bark) & $\begin{array}{l}\text { Purata durasi } \\
\text { dan SD } \\
\text { (msaat) }\end{array}$ \\
\hline $\begin{array}{l}\text { B1 } \\
\text { /i/ }\end{array}$ & $\begin{array}{l}368 \\
(35.68)\end{array}$ & $\begin{array}{l}2508 \\
(470.34)\end{array}$ & 3.55 & 14.53 & $\begin{array}{l}75.51 \\
(15.92)\end{array}$ \\
\hline $\begin{array}{l}\text { B2 } \\
\text { /i://// }\end{array}$ & $\begin{array}{l}352-344 \\
(50.39)-(29.30)\end{array}$ & $\begin{array}{l}2552-2574 \\
(501.99)-(309.11)\end{array}$ & $3.41-3.33$ & $14.64-14.69$ & $\begin{array}{l}195.35-119.05 \\
(80.95)-(33.18)\end{array}$ \\
\hline $\begin{array}{l}\text { B3 } \\
\text { /i:/-// } /\end{array}$ & $\begin{array}{l}321-355 \\
(28.95)-(52.90)\end{array}$ & $\begin{array}{l}2626-2586 \\
(384.58)-(308.04)\end{array}$ & $3.12-3.43$ & $14.81-14.72$ & $\begin{array}{l}221.10-81.25 \\
(84.04)-(16.11)\end{array}$ \\
\hline
\end{tabular}


POLA SEBUTAN MONOFTONG BAHASA JERMAN OLEH PENUTUR BAHASA MELAYU

Jadual 6 Purata kesemua vokal/e/ bagi B1, B2 dan B3.

\begin{tabular}{|c|c|c|c|c|c|}
\hline Bahasa & $\begin{array}{lr}\text { Purata } & \text { F1 } \\
\text { dan SD }(\mathrm{Hz})\end{array}$ & $\begin{array}{l}\text { Purata F2 dan } \\
\text { SD (Hz) }\end{array}$ & $\begin{array}{ll}\text { F } 1 \\
\text { (Bark) }\end{array}$ & $\begin{array}{ll}\text { F } 2 \\
\text { (Bark) }\end{array}$ & $\begin{array}{l}\text { Purata durasi } \\
\text { dan SD (msaat) }\end{array}$ \\
\hline $\begin{array}{l}\text { B1 } \\
/ \mathbf{e} /\end{array}$ & $\begin{array}{l}514 \\
(82.41)\end{array}$ & $\begin{array}{l}2379 \\
(230.45)\end{array}$ & 4.86 & 14.20 & $\begin{array}{l}83.07 \\
(11.04)\end{array}$ \\
\hline $\begin{array}{l}\mathbf{B 2} \\
/ \varepsilon /\end{array}$ & $\begin{array}{l}678 \\
(114.70)\end{array}$ & $\begin{array}{l}2263 \\
(273.46)\end{array}$ & 6.22 & 13.89 & $\begin{array}{l}157.65 \\
(55.25)\end{array}$ \\
\hline $\begin{array}{l}\text { B3 } \\
\text { /e:/ }\end{array}$ & $\begin{array}{l}579 \\
(150.99)\end{array}$ & $\begin{array}{l}2354 \\
(290.85)\end{array}$ & 5.41 & 14.14 & $\begin{array}{l}159.55 \\
(48.43)\end{array}$ \\
\hline
\end{tabular}

Berdasarkan Jadual 6, purata durasi yang terpendek boleh dilihat daripada B1 pada kadar 83.07 milisaat, manakala /e:/ B3 pula memiliki kadar yang terpanjang, iaitu 159.55 milisaat. Perbezaan kadar purata durasi yang ketara boleh dilihat antara kedua-duanya dengan perbezaan sebanyak 76.48 milisaat.

\section{F2 (Bark)}

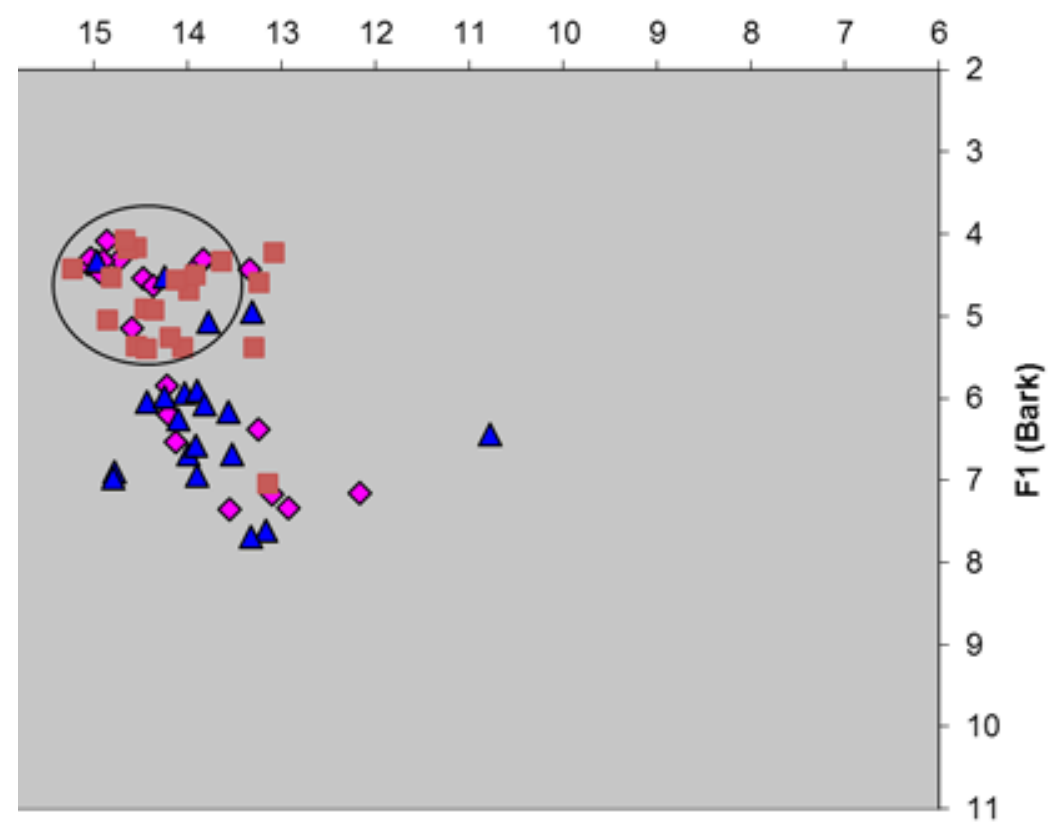

Rajah 7 Taburan vokal /e:/ B1, /\&/ B2 dan /e:/ B3. 
Daripada Rajah 7, didapati bahawa sebutan /e:/ - /E/ - /e/ oleh penutur adalah berselerak dalam ruang vokal. Pertindihan antara /e:/ - /E/ - /e/ dapat dilihat dalam Rajah tersebut.

Ujian Friedman menunjukkan terdapat perbezaan yang signifikan bagi F1 antara ketiga-tiga vokal ini, $\chi^{2}(2, \mathrm{~N}=20)=15.6, \mathrm{p}<0.05$. Perbezaan ini dapat dijangka memandangkan /E/ dalam B2 adalah lebih rendah daripada vokal /e/ B1 dan /e:/ B3 (Stefanie, 2014; Tan \& Low, 2010). Namun begitu, ujian post hoc Tukey dan Wilcoxon Signed-ranks pula menunjukkan, antara F1 /e/ B1 dan /e:/ B3 tidak terdapat perbezaan yang signifikan, iaitu, $Z=1.53, p=0.13, r=0.26$. Berdasarkan ujian Friedman bagi nilai $\mathrm{F} 2$ pula, didapati tiada perbezaan yang signifikan antara /e:/ $/ \varepsilon /$ - /e/, iaitu $\chi^{2}(2, \mathrm{~N}=20)=2.8, \mathrm{p}=0.25$.

Berdasarkan ujian sama, terdapat perbezaan yang signifikan antara durasi bagi / e: $/ / \varepsilon /$ - /e/, iaitu $\chi^{2}(2, N=20)=30.4, p<0.05$. Walau bagaimanapun, melalui ujian post hoc Tukey dan Wilcoxon Signed-ranks, perbezaan durasi antara /e:/ B3 dan /E/ B2 adalah tidak signifikan, $Z=0.04, p=0.97, r=0.02$. Dapatan ini selari dengan dapatan pada fonem /i/, apabila penutur kajian menyamakan /e/ B1 dan /e:/ B3 dari sudut kualiti, namun menggunakan kepanjangan /E/ B2 untuk /e:/ B3 mereka.

Jadual 7 memaparkan purata F1, F2 dan durasi kesemua fonem /u/ B1, B2 dan B3 bagi memudahkan perbandingan. Jurang perbezaan purata durasi juga didapati agak besar dengan nilai terpendek ialah /u/ B1 pada ukuran 96.95 milisaat, diikuti dengan /u:/ B3 pada kadar 205.55 milisaat dan /u:/ B2 pada 219.75 milisaat. Rajah 8

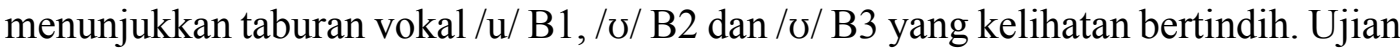
Friedman menunjukkan tiada perbezaan yang signifikan bagi $\mathrm{F} 1$ antara ketiga-tiga vokal ini, $\chi^{2}(2, \mathrm{~N}=20)=1.3, \mathrm{p}=0.52$. Berdasarkan ujian Friedman bagi nilai $\mathrm{F} 2$ pula, didapati terdapat perbezaan yang signifikan antara $/ \mho /-/ \mho /-/ \mathrm{u} /$, iaitu $\chi^{2}(2$, $\mathrm{N}=20)=8.58, \mathrm{p}<0.05$. Namun begitu, melalui ujian post hoc Tukey dan Wilcoxon

Jadual 7 Purata vokal /u/ kesemua bahasa.

\begin{tabular}{|c|c|c|c|c|c|}
\hline Bahasa & $\begin{array}{l}\text { Purata F1 dan } \\
\text { SD (Hz) }\end{array}$ & $\begin{array}{c}\text { Purata F2 dan SD } \\
(\mathrm{Hz})\end{array}$ & F1 (Bark) & F2 (Bark) & $\begin{array}{c}\text { Purata durasi } \\
\text { dan SD (msaat) }\end{array}$ \\
\hline $\begin{array}{l}\text { B1 } \\
/ \mathbf{u} /\end{array}$ & $\begin{array}{l}393 \\
(48.26)\end{array}$ & \begin{tabular}{|l|}
1104 \\
$(141.19)$
\end{tabular} & 3.79 & 9.15 & $\begin{array}{l}96.95 \\
(24.54)\end{array}$ \\
\hline $\begin{array}{l}\mathbf{B 2} \\
/ \mathbf{u}: / / / \mho /\end{array}$ & $\begin{array}{l}404-396 \\
(56.98)-(41.09)\end{array}$ & \begin{tabular}{|l|}
$1046-1211$ \\
$(149.65)-(151.63)$
\end{tabular} & $3.88-3.81$ & $8.80-9.76$ & $\begin{array}{l}219.75-91.95 \\
(76.42)-(17.63)\end{array}$ \\
\hline $\begin{array}{l}\mathbf{B 3} \\
/ \mathbf{u}: /-/ \mho /\end{array}$ & $\begin{array}{l}377-399 \\
(37.54)-(55.22)\end{array}$ & \begin{tabular}{|l|}
$1212-1149$ \\
$(288.45)-(173.76)$
\end{tabular} & $3.63-3.84$ & $9.77-9.41$ & $\begin{array}{l}205.55-131.80 \\
(46.98)-(44.38)\end{array}$ \\
\hline
\end{tabular}




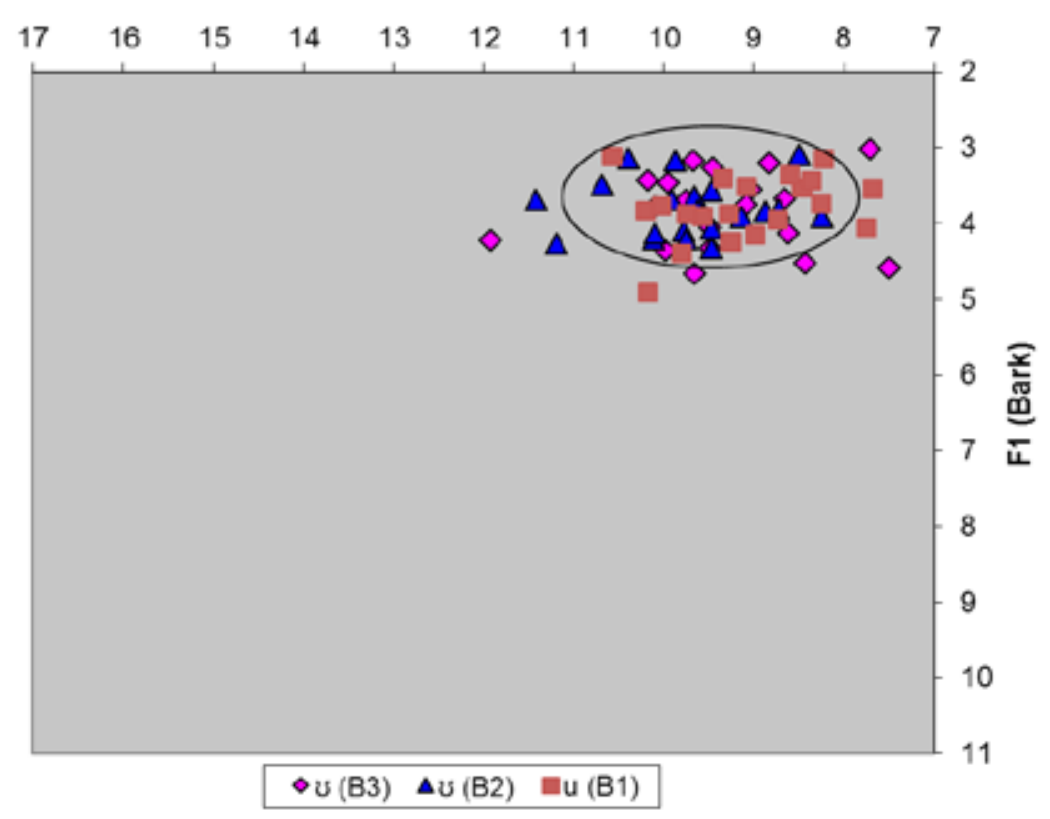

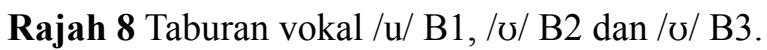

Signed-ranks, tidak terdapatnya perbezaan yang signifikan bagi F2 /u/ B1 dan / / B3, iaitu, $\mathrm{Z}=0.93, \mathrm{p}=0.35, \mathrm{r}=0.14$. Walau bagaimanapun, berdasarkan ujian Post hoc Tukey dan Wilcoxon Signed-ranks, tidak terdapat perbezaan yang signifikan bagi durasi $/ \mathrm{u} / \mathrm{B} 1$ dan $/ \mho / \mathrm{B} 2, \mathrm{Z}=0.95, \mathrm{p}=0.34, \mathrm{r}=0.12$. Daripada dapatan ujian tersebut, penutur kajian telah menyamakan vokal /u/ B1 dan/ひ/ B3, serta hanya membezakan kadar panjang bagi kedua-duanya. Sungguhpun begitu, kadar panjang vokal / / B3 tersebut tidaklah pula menyamai kadar panjang vokal/ひ/ B2.

Rajah 9 menunjukkan taburan vokal /u/ B1, /u:/ B2 dan /u:/ B3 yang kelihatan berselerak. Ujian Friedman menunjukkan terdapat perbezaan yang signifikan bagi F1 antara ketiga-tiga vokal ini, $\chi 2(2, \mathrm{~N}=20)=7.68, \mathrm{p}<0.05$. Walau bagaimanapun, perbandingan kadar F1 antara/u/ B1 dan/u:/ B3 serta/u/ B1 dan /u:/ B2 melalui ujian Wilcoxon Signed-ranks dan dapatan daripada ujian Post hoc Tukey, menunjukkan perbezaan yang tidak signifikan pada kadar $Z=1.79, p=0.07, r=0.1$ serta $Z=1.05$, $\mathrm{p}=0.29, \mathrm{r}=0.1$. Berdasarkan ujian Friedman, nilai F2 fonem /u: - /u: / / $/$ t tidak mempunyai perbezaan yang signifikan, iaitu $\chi^{2}(2, \mathrm{~N}=20)=1.68, \mathrm{p}=0.43$. 


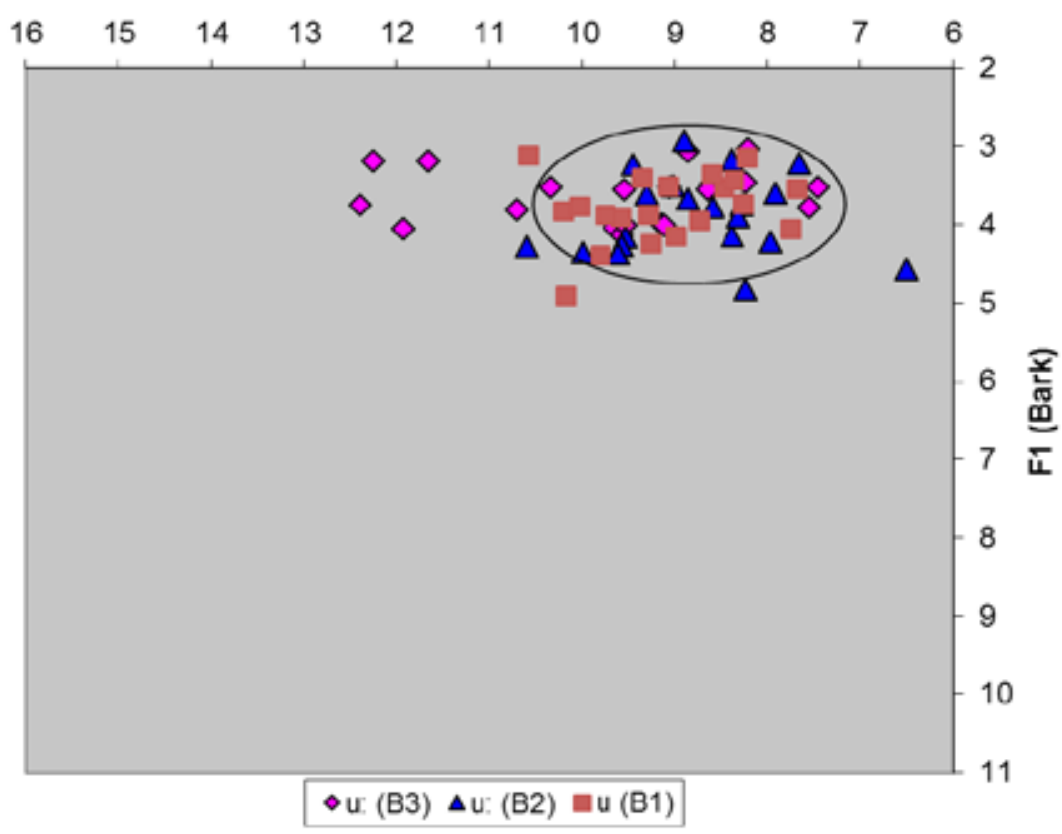

Rajah 9 Taburan vokal /u/ B1, /u:/ B2 dan /u:/ B3.

Berpandukan ujian yang sama, dari sudut durasi terdapat perbezaan yang signifikan bagi /u:/ - /u:/ - /u/ pada $\chi^{2}(2, \mathrm{~N}=20)=30.1, \mathrm{p}<0.05$. Namun begitu, ujian Post hoc Tukey dan Wilcoxon Signed-ranks menunjukkan tidak terdapatnya perbezaan yang signifikan antara durasi /u:/ B2 dan /u:/ B3, $\mathrm{Z}=0.49, \mathrm{p}=0.62, \mathrm{r}=$ 0.27. Keadaan ini menunjukkan seperti dapatan pada vokal /i/ dan /e/, penutur kajian telah menyelaraskan sebutan /u:/ B3 dalam ruang vokal yang sama dengan B1, tetapi menggunakan kadar panjang /u:/ B2 untuk menyebut /u:/ B3 mereka.

Pertindihan yang berlaku antara vokal/ð/ dan /ø:/ dalam B3 menyebabkan fonem /ø:/ turut dibandingkan dengan/u/ B1,/v/ dan/u:/ B2 (lihat Rajah 10). Ujian Friedman menunjukkan tidak terdapat perbezaan yang signifikan bagi F1 antara ketiga-tiga vokal /u/ B1, / / B2 dan /ø:/ B3 ini, $\chi^{2}(2, \mathrm{~N}=20)=1.3, \mathrm{p}=0.52$. Berdasarkan ujian yang sama bagi nilai F2 pula, didapati terdapat perbezaan yang signifikan kepada ketiga-tiganya, iaitu $\chi^{2}(2, \mathrm{~N}=20)=6.4, \mathrm{p}<0.05$. Hasil ujian Wilcoxon Signed-ranks antara F2 /ø:/ B3 dan/ð/ B2, pula menunjukkan tidak terdapatnya perbezaan yang signifikan, iaitu $\mathrm{Z}=0.90, \mathrm{p}=0.37, \mathrm{r}=0.11$ dan dapatan ini adalah selaras dengan 


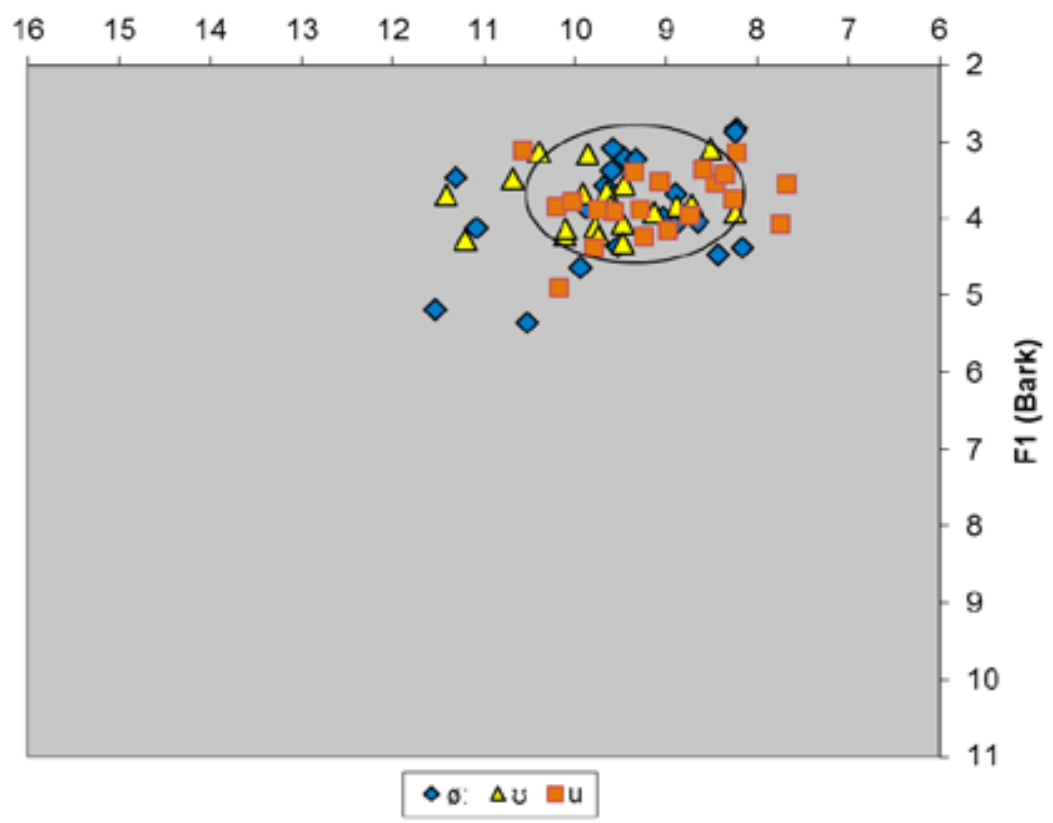

Rajah 10 Taburan vokal/u/ B1, /ø/ B2 dan /ø:/ B3.

ujian Post hoc Tukey. Ujian Wilcoxon Signed-ranks turut dilakukan terhadap fonem panjang /u:/ B2 dan /ø:/ B3. Hasil ujian turut mendapati tidak terdapat perbezaan yang signifikan, iaitu $F 1, Z=0.11, p=0.91, r=0.01$ pada kedua-dua fonem tersebut, namun terdapat perbezaan yang signifikan pada $F 2$ nya, $Z=2.29, \mathrm{p}<0.05, \mathrm{r}=0.36$.

Dari sudut durasi pula, ujian Friedman terhadap /ø:/ - / / - /u/ serta ujian Wilcoxon Signed-ranks terhadap /u:/ B2 dan /ø:/ B3 menunjukkan terdapat perbezaan yang signifikan bagi kesemua fonem, iaitu $\chi 2(2, N=20)=30.9, p<0.05$ serta $Z=2.07$, $\mathrm{p}<0.05, \mathrm{r}=0.22$. Keadaan ini menunjukkan, penutur menganggap bunyi /ø:/ B3 menyamai /u:/ B2 dari sudut kualiti, namun hanya mempunyai ketinggian yang sama dengan /u/ B1. Sungguhpun begitu, penutur kajian menganggap ketiga-tiga bahasa memiliki kadar panjang yang berbeza. Dapatan ini selaras dengan model bahasa kedua (SLM) Flege (1995) dan model pembelajaran B3 Gut (2010).

Rajah 11 memperlihatkan pertindihan antara /o/ - /p/ - /o/. Ujian Friedman menunjukkan tidak terdapat perbezaan yang signifikan bagi $\mathrm{F} 1$ antara ketiga-tiga vokal ini, $\chi^{2}(2, \mathrm{~N}=20)=3.1, \mathrm{p}=0.21$. Berdasarkan ujian yang sama bagi nilai $\mathrm{F} 2$ 
F2 (Bark)

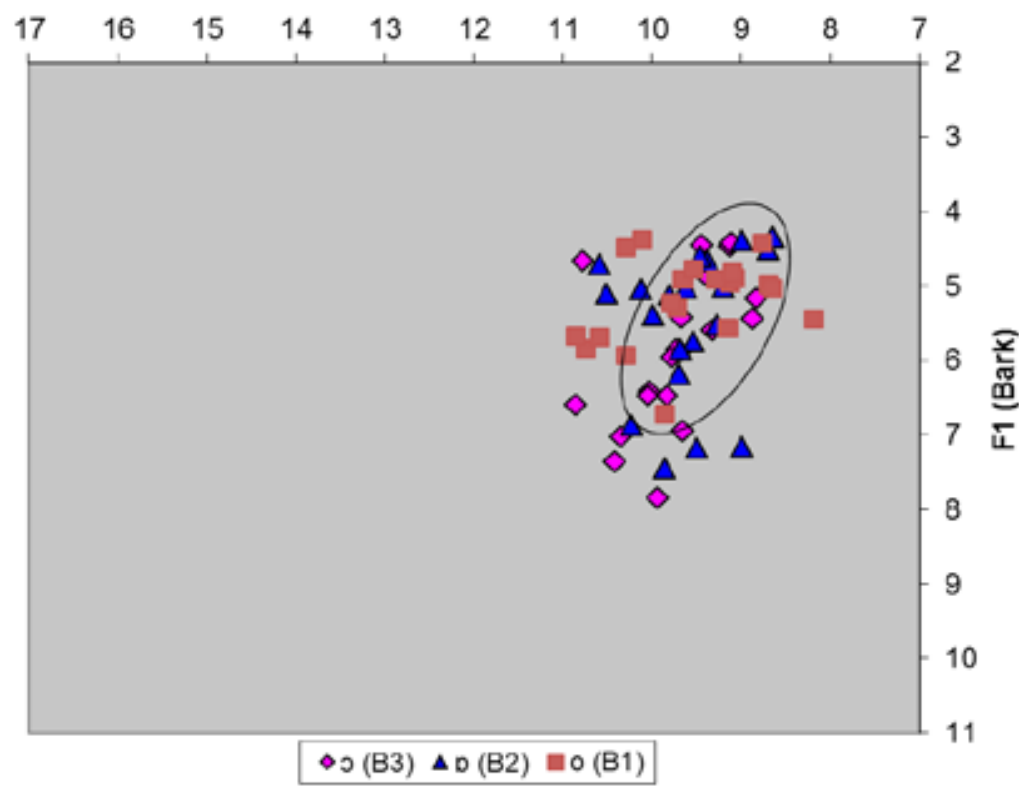

Rajah 11 Taburan vokal/o/ B3, /p/ B2 serta/o/ B1.

pula, turut didapati tiada perbezaan yang signifikan antara $/ \mathrm{s} /-/ \mathrm{p} /-/ \mathrm{o} /$, iaitu $\chi^{2}(2$, $\mathrm{N}=20)=2.7, \mathrm{p}=0.26$.

Dari sudut durasi pula, hasil daripada ujian yang sama menunjukkan terdapatnya perbezaan yang signifikan pada $\chi^{2}(2, \mathrm{~N}=20)=20.1, \mathrm{p}<0.05$ bagi kesemua vokal. Walau bagaimanapun, berdasarkan ujian Post hoc Tukey dan Wilcoxon Signed-ranks, kesemua fonem $/ \mathrm{o} /-/ \mathrm{p} / \mathrm{-} / \mathrm{o} /$ mempunyai perbezaan yang signifikan pada kadar $\mathrm{p}$ $<0.05$, namun /o/ B1 dan /o/ B3 tidak mempunyai perbezaan yang signifikan pada $\mathrm{p}<0.01$, iaitu $\mathrm{Z}=1.98, \mathrm{p}=0.05, \mathrm{r}=0.27$. Hasil dapatan ini menjadikan, sebutan bagi ketiga-tinganya adalah hampir sama dari sudut kualiti dan durasi. Keadaan ini menunjukkan, bunyi vokal /o/ B1 telah diasimilasi oleh penutur kajian ke dalam bunyi /o/ B3. Keputusan ini selaras dengan pendapat Lado (1964) dan Littlewood (1984) yang menganggap bahasa pertama sedikit sebanyak akan mempengaruhi dan mengganggu pembelajaran bahasa seterusnya.

Pertindihan antara /a/ B3, / / B 2 dan /a/ B1 dapat dilihat dengan jelas dalam Rajah 12. Ujian Friedman menunjukkan tiada perbezaan yang signifikan bagi F1 antara ketiga-tiga vokal ini pada $\chi^{2}(2, N=20)=1.3, p=0.52$. Berdasarkan ujian yang 


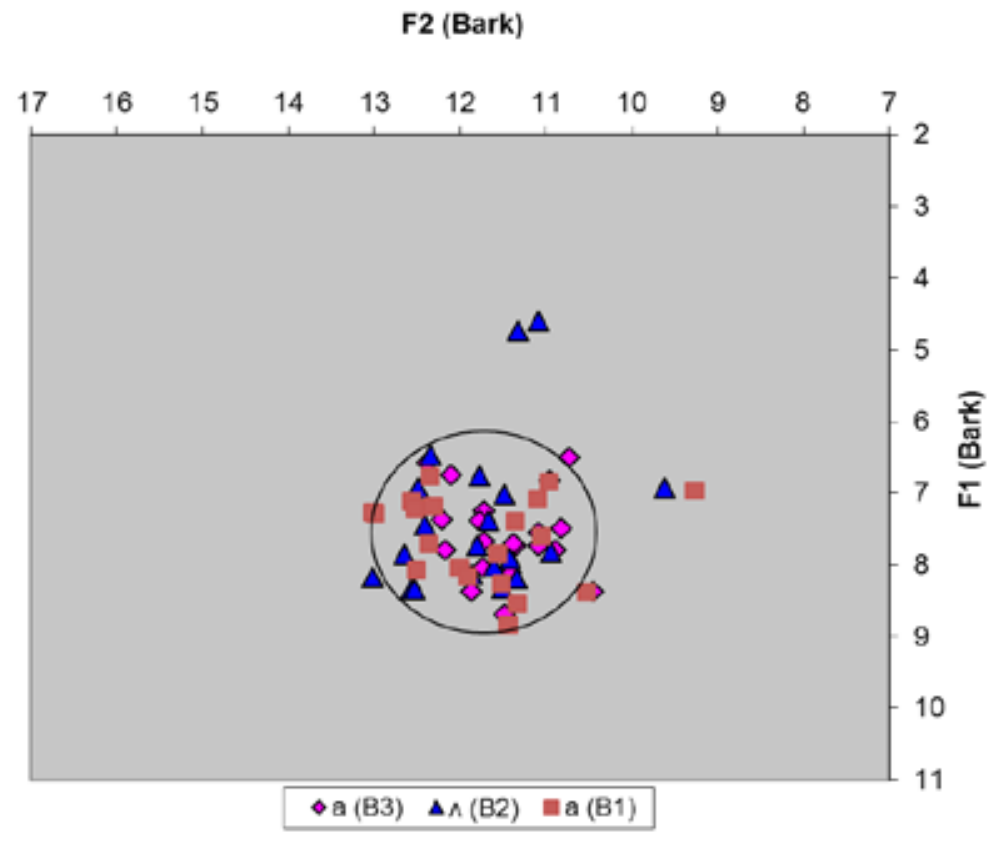

Rajah 12 Taburan vokal /a/ B3, / / B2 dan /a/ B1.

sama bagi nilai F2 pula, juga didapati tiada perbezaan yang signifikan antara $/ \mathrm{a} / \mathrm{-} / \mathrm{\Lambda} /$ - /a/, iaitu $\chi^{2}(2, N=20)=4.9, p=0.09$.

Ujian Friedman turut dilakukan terhadap nilai durasi ketiga-tiga fonem. Berdasarkan ujian tersebut, didapati terdapatnya perbezaan yang signifikan bagi /a/ $/ \Lambda /$ - /a/ pada $\operatorname{kadar} \chi^{2}(2, N=20)=6.4, p<0.05$. Namun begitu, hasil ujian Wilcoxon Signed-ranks menunjukkan tidak terdapatnya perbezaan yang signifikan antara $/ \mathrm{N} /$ $\mathrm{B} 2$ dan /a/ B3 tersebut, $Z=1.42, p=0.16, r=0.04$. Keadaan ini menunjukkan bahawa penutur kajian menganggap ketiga-tiganya adalah sama dari sudut kualiti. Dapatan ini sudah dijangka berikutan pertindihan taburan vokal yang sekata dalam Rajah 12. Selain itu, dapatan juga selaras dengan pendapat pengkaji terdahulu (Jørgensen, 1969; Antoniadis \& Strube 1984 dalam Mayr \& Escudero, 2010).

Berikutan daripada pertindihan antara /a:/ B2 dan /a:/ B3 dalam Rajah 13, satu ujian Wilcoxon Signed-ranks turut dilakukan terhadap kedua-dua fonem panjang tersebut. Hasil ujian mendapati tidak terdapatnya perbezaan yang signifikan pada F1 dan F2 fonem /a:/ B2 dan /a:/ B3, iaitu $Z=1.96, p=0.05, r=0.17$ dan $Z=0.67, p$ $=0.50, r=0.09$. Dari sudut durasi pula, ujian Wilcoxon Signed-ranks menunjukkan terdapat perbezaan yang signifikan antara kedua-duanya, iaitu $Z=2.43, p<0.05$, $r=0.30$. 


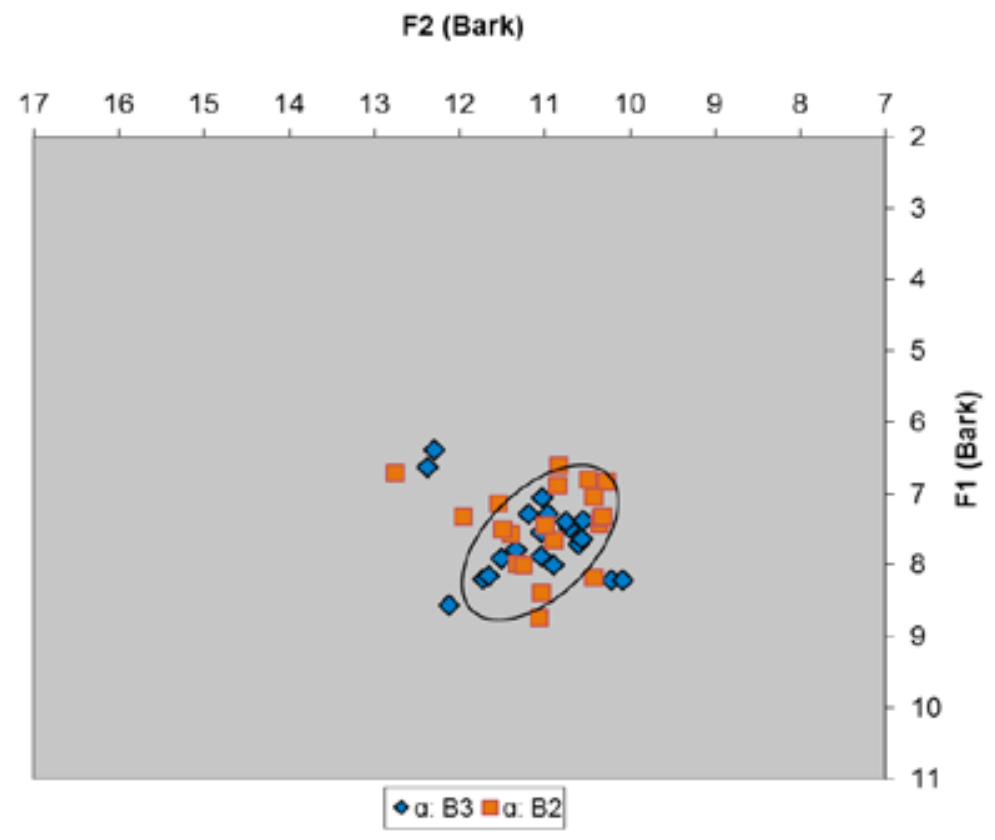

Rajah 13 Taburan vokal /a:/ B2 dan /a:/ B3.

Bagi pasangan /a/ B1 dan /a:/ B3 pula, hanya kadar F1 yang memperoleh dapatan yang tidak signifikan, iaitu $Z=0.22, p=0.82$. Sungguhpun terdapat perbezaan durasi yang signifikan antara fonem /a:/ B2 dan /a:/ B3, namun hal ini tidak berlaku terhadap fonem /a/ B1. Berdasarkan dapatan ini, boleh dirumuskan bahawa penutur kajian telah menghasilkan suatu bunyi /a:/ B3 yang baharu, kerana penutur tidak membezakan kadar durasi serta F2 antara /a/ B1 - /a:/ B3. Perlu diingat bahawa dalam bahasa Jerman, perbezaan antara vokal /a/ - /a:/ hanyalah pada kadar durasinya sahaja (Antoniadis \& Strube, 1984; Jørgensen, 1969). Penghasilan fonem baharu ini selaras dengan hipotesis Hammarberg dan Hammarberg (2005) serta kajian daripada Bohn dan Flege (1992), Gut (2010) dan Wrembel (2014).

\section{RUMUSAN}

Secara umumnya, penutur kajian telah menghasilkan bunyi monoftong B3 /I/, /i:/,

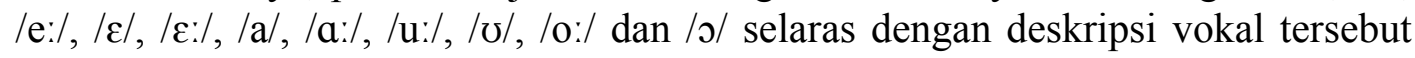
dalam bahasa Jerman Standard (BJS). Selain itu didapati juga, vokal /i:/, /y:/, /a:/, / 
o:/ dan /ø:/ berada pada kedudukan yang lebih sisi di dalam ruang vokal berbanding pasangan vokal pendeknya.

Bagi monoftong B1, kesemua enam vokal wujud dalam kajian dan turut selaras dengan kajian impresionistik terdahulu. Memandangkan semua penutur ialah penutur natif B1, dapatan ini sudah dapat dijangkakan. Dari sudut akustik, sedikit perbezaan berbanding kajian terdahulu didapati bagi dua vokal, iaitu /a/ dan /u/ kerana bagi vokal /a/, kedudukannya lebih rendah manakala /u/ pula lebih belakang dalam ruang vokal (Mardian, 2005; Shaharina \& Shahidi, 2012). Perbezaan yang berlaku ini mungkin disebabkan oleh instrumen kajian yang berbeza.

Perbandingan bagi semua monoftong B2 dengan deskripsinya adalah selaras dengan kajian-kajian terdahulu (Stefanie, Manueli \& Dumanig, 2010; Stefanie et al., 2010; Tan \& Low, 2010). Seperti dalam kajian di atas, inventori vokal B2 berkemungkinan lebih kecil daripada bahasa Inggeris British. Keadaan ini berlaku akibat sesetengah vokal yang tidak dibezakan oleh penutur kajian. Umpamanya pasangan vokal /I/ - /i:/ tidak dibezakan oleh penutur kajian, sedangkan kedua-dua vokal tersebut seharusnya turut berbeza dari sudut kualiti. Selain itu, terdapat sedikit perbezaan bagi kedudukan vokal /3:/, /p/ dan /o:/ dengan dapatan daripada kajian berkaitan MalE terdahulu (Stefanie et al., 2010; Tan \& Low, 2010). Tidak dinafikan bahawa perbezaan ini juga mungkin disebabkan oleh keadaan penyelidikan yang berbeza. Bagi vokal-vokal lain, walaupun kedudukannya tidak sepenuhnya serupa dengan kajian terdahulu, namun masih boleh dianggap berada di kawasan yang berhampiran dalam ruang vokal.

Secara keseluruhannya, enam monoftong B3, iaitu /I/, /e:/, / /, /u:/, /o/ dan /a/ disebut serupa oleh penutur kajian dengan vokal /i/, /e/, /u/,/o/ dan /a/ dalam B1 mereka. Persamaan sepenuhnya dari sudut kualiti dan durasi turut berlaku ke atas vokal /I/ B3 dan /i/ B1 menjadikan kualiti kedua-duanya sama. Berdasarkan dapatan kajian, vokal /I/ B3 turut menyamai vokal/I/ dan/i:/ B2, namun pada kadar durasi yang lebih pendek daripada kedua-duanya. Keadaan ini mungkin berlaku kerana dari sudut kualiti, /I/ dan /i:/ B2 penutur kajian turut dipengaruhi oleh /i/ B1, kerana persepsi bunyi dan produksinya telah dianggap serupa serta bunyi /i/ dari B1 tersebut menjadi penghalang penguasaan sebutan /I/ dan /i:/ B2 secara autentik (rujuk juga Flege, 1995).

Bagi vokal/e:/ dan/u:/ B3, kualiti kedua-duanya menyamai/e/ dan/u/B1, namun durasinya menyamai $/ \varepsilon /$ dan /u:/ B2, menjadikannya dipengaruhi oleh kedua-dua bahasa (B1 dan B2), serta menyebabkan terbentuknya vokal yang mempunyai ciri yang agak kompleks. Vokal luas /a/ B3 turut menyamai vokal /a/ B1, namun ia lebih panjang dari vokal B1 tersebut. Selain itu, vokal /a/ B3 ini juga didapati menyamai sepenuhnya (kualiti dan durasi) vokal $/ \Lambda / \mathrm{B} 2$. Keadaan ini menunjukkannya lebih dipengaruhi oleh $\mathrm{B} 2$ penutur kajian dan mungkin juga kerana perkataan bud dan batt bagi kedua-dua bahasa (B2 dan B3) tersebut mempunyai bunyi yang hampir sama 
(lihat Jadual 1). Seperti juga dalam kajian MalE yang lain, dapat dilihat bahawa $/ \mathrm{N}$ dan /a:/ yang disebut oleh penutur adalah berdekatan antara satu sama lain dalam ruang vokal (lihat Jadual dan Rajah 4). Bagi dua vokal/ひ/ dan /o/ pula, durasi keduaduanya adalah berbeza daripada B1 dan B2 penutur kajian. Vokal/ひ/ B3 didapati lebih panjang daripada/u/ B1 dan/ð/B2, bagi /o/ B3 adalah lebih panjang daripada/o/ B1 namun lebih pendek daripada / $/$ / B2. Keadaan ini menyebabkan vokal / $/$ hanya dipengaruhi oleh kualiti vokal B1 dan B2, namun dengan kadar panjang yang berbeza. Sementara itu, vokal / $/$ pula hanya mempunyai ketinggian yang serupa dengan / $/$ B2, namun pada keluasan dan durasi yang berbeza. Rumusan berkaitan ciri vokal B3 di sini adalah lebih kompleks namun selaras dengan model pembelajaran B3 oleh Gut (2010) dan pengaruh ciri antara bahasa (interlanguage) oleh Selinker (1972).

Terdapat juga sebahagian monoftong B3 yang lebih menyamai monoftong B2. Vokal panjang /ø:/ dan/a:/ B3 misalnya, didapati mempunyai kualiti yang sama dengan vokal /ð/ dan /a:/ B2. Walau bagaimanapun, kedua-dua vokal B3 tersebut adalah lebih panjang daripada kedua-dua vokal B2 penutur kajian. Vokal /ひ/ B3 pula didapati mempunyai ketinggian yang serupa dengan/ð/B2. Satu lagi vokal B3, iaitu/i:/ didapati menyamai vokal /i:/ B2. Namun begitu, persamaan yang wujud antara kedua-duanya hanyalah dari sudut durasi. Sementara kualiti vokal /i:/ B3 tersebut adalah berbeza daripada /i:/ B2 mahupun /i/ B1 kerana vokal ini didapati lebih tinggi. Pengaruh B2 yang lebih besar terhadap /ø:/ dan /a:/ ini dilihat selaras dengan hipotesis Hammarberg dan Hammarberg (2005) melalui strategi "bunyi tidak seperti penutur natif B1".

Vokal-vokal B3 yang tidak wujud serta tidak setara dengan mana-mana vokal dalam B1 mahupun B2, seperti /Y/, /y:/, /ع/, / $:$ :/ dan /œ/ telah dihasilkan oleh penutur kajian pada kualiti yang berlainan berbanding dengan bahasa Jerman sebutan natif (Brenner, Huszka \& Werk-Marinkás, 2006; Delattre, 1964). Kesemua lima vokal tersebut juga didapati berada pada kedudukan dalam ruang vokal yang tidak menyamai mana-mana vokal dalam B1 dan B2 penutur kajian. Keadaan ini selaras dengan model SLM oleh Flege (1995) dan model pembelajaran B3 oleh Gut (2010). Selain itu, terdapat juga vokal yang dilihat setara dengan B1 namun hasil dapatan menunjukkannya mempunyai kualiti yang berbeza. Misalnya vokal /o:/ B3 yang mempunyai keluasan lidah yang hampir dengan /o/ B1. Namun begitu, ia didapati terhasil pada kedudukan yang lebih rendah serta jauh lebih panjang daripada B1. Berbanding dengan B2 yang tidak memiliki kualiti vokal yang sama dengan /o:/ B3 ini serta perbezaan yang signifikan dengan /o/ B1, bolehlah dikatakan bahawa penutur kajian telah menghasilkan satu vokal dengan kualiti yang baharu bagi B3 tersebut. Dapatan bagi vokal /o:/ B3 ini didapati turut selaras dengan kajian ahli linguistik terdahulu seperti Gut (2010) dan Selinker (1972) namun sedikit bercanggah dengan model bahasa kedua Flege (1995). 


\section{KESIMPULAN}

Kesimpulannya, B1 dalam kajian ini mempunyai pengaruh yang lebih besar terhadap B3 penutur kajian. Namun begitu, perlu ditekankan juga bahawa B2 penutur kajian berkemungkinan besar telah turut dipengaruhi oleh B1 (lihat Tan \& Low 2010). Oleh itu, bolehlah dirumuskan bahawa terdapat pengaruh silang linguistik (cross linguistic influence) bagi sebutan vokal-vokal tertentu dalam B3 yang lebih dipengaruhi oleh B1 dan bukannya B2 penutur kajian. Selain $C L I$, pengaruh vokal B1 terhadap B3 yang lebih besar dalam kajian ini turut selaras dengan rumusan yang dibuat oleh Hammarberg dan Hammarberg (2005) dalam Marx dan Melhorn (2010), iaitu pengaruh penetapan bunyi B1 merupakan kekangan asas dan cenderung untuk berterusan dalam pembelajaran bahasa. Bagi vokal B3 yang tiada vokal berhampiran yang sama dalam B1 atau B2, boleh dianggap bahawa penutur berusaha menghasilkan bunyi vokal asing B3 tersebut tanpa pengaruh daripada B1, B2 . Namun begitu, berdasarkan kualiti vokal tersebut, sebutan penutur kajian tidak menyerupai BJS. Hal ini berlaku mungkin kerana mereka masih pada tahap pembelajaran awal dan juga disebabkan mereka tidak berada dalam konteks persekitaran bahasa Jerman standard (BJS) dituturkan. Selain itu, terdapat juga vokal-vokal B3 yang mempunyai sebahagian pengaruh daripada B1 dan sebahagian lagi dipengaruhi oleh B2. Dari sudut perbandingan dengan BJS kajian terdahulu, didapati monoftong B3 penutur kajian mempunyai kadar penyerakan yang lebih kecil dan menjadikannya disebut secara tidak sama berbanding dengan penutur natif.

Sebagai penutup, sungguhpun model pembelajaran B2 (Flege, 1995) tidak sepenuhnya bertepatan dengan kajian ini, namun terdapat juga bukti yang menunjukkan bahawa penutur kajian telah menyamakan sepenuhnya vokal-vokal B3 yang dianggap mempunyai produksi yang hampir dengan B1 serta B2 mereka.

Diharap kajian ini dapat menyumbang kepada usaha memperkaya pengajaran dan pembelajaran (P\&P) bahasa asing di Malaysia. Kajian ini hanyalah tertumpu pada penutur perempuan dari sebuah institusi pengajian sahaja. Oleh itu, kajian ini tidak sah bagi penutur lelaki mahupun pelajar B3 dari institusi pengajian tinggi yang lain. Berdasarkan limitasi tersebut, diharap juga terdapat para pengkaji lain yang sudi untuk membuat kajian seumpama ini dengan skala dan skop yang lebih luas. Semoga lebih ramai golongan yang menguasai bahasa-bahasa asing serta berkemahiran dalam berbahasa, tanpa perlu mengabaikan bahasa ibunda kita sendiri. 


\section{RUJUKAN}

Adank, P., Smits, R., \& Hout, R. (2004). A Comparison of Vowel Normalization Procedures for Language Variation Research. Journal of the Acoustical Society of America, 116, 3099-3107.

Antoniadis, Z., \& Strube, H. (1984). Untersuchungen zur spezifischen Dauer deutscher Vokale. Phonetica, 72-87.

Aoyama, K. et al. (2004). Perceived Phonetic Diddimilarity and L2 Speech Learning: The Case of Japanese /r/ and English /1/ and /r/. Journal of Phonetics, 233-250.

Asmah Haji Omar. (1988). Susur Galur Bahasa Melayu. Kuala Lumpur: Dewan Bahasa dan Pustaka.

Boersma, P., \& Weenink, D. (2013, October 27). Praat: Doing Phonetics by Computer. Amsterdam, Netherlands. Akses pada November 5th, 2013, daripada http://www.fon. hum.uva.nl/praat/

Bohn, O.-S., \& Flege, J. E. (1992). The Production of New and Similar Vowels by Adult German Learners of English. Studies in Second Language Acquisition, 14(2), 131-158.

Brenner, K., Huszka, B., \& Werk-Marinkás, C. (2006). Deutsche Phonetik: Eine Einführung. Budapest: Bölcsész Konzorcium.

Delattre, P. (1964). Comparing the Vocalic Features of English, German, Spanish and French. International Review of Applied Linguistics in Language Teaching, 2(2), 71-97.

Escudero, P., \& Williams, D. (2011). Perceptual Assimilation of Dutch Vowels by Peruvian Spanish Listeners. The Journal of the Acoustical Society of America.

Flege, J. E. (1995). Second Language Speech Learning Theory, Findings, and Problems. Strange, W. (Ed), Speech Perception and Linguistic Experience: Issues in CrossLanguage Research (pp. 233-277). Timonium, MD: York Press.

Fry, D. B. (1979). The Physics of Speech. Cambridge: Cambridge University Press

Guion, S. G., Flege, J. E., Yamada, R. A., \& Pruitt, J. C. (2000). An Investigation of Current Models of Second Language Speech Perception: The Case of Japanese Adults' Perception of English Consonants. Journal of Acoustical Society of America, 107, 2711-2724.

Gut, U. (2010). Cross-linguistic Influence in L3 Phonological Acquisition. International Journal of Multilingualism, 7(1), 19-38.

Hammarberg, B., \& Hammarberg, B. (2005). Re-setting the basis of articulation in the acquisition of new languages: A third-language case study. B. Hufeisen, \& R. Fouser (Ed.), Introductory Readings in L3 (pp. 11-18). Tubingen: Stauffenburg.

Abdullah Hassan. (2005). Linguistik Am. Siri Pengajaran dan Pembelajaran Bahasa Melayu. Selangor: PTS Professional Publishing Sdn. Bhd.

Iverson, P., \& Evans, B. G. (2007). Learning English Vowels With Different First-Language Vowel Systems: Perception of Formant Targets, Formant Movement, and Duration. Journal of the Acoustical Society of America, 122(5), 2842-2854. 
Jørgensen, H. P. (1969). Die gespannten und Ungespannten Vokale in der Norddeutschen Hochsprache mit Einer Spezifischen Untersuchung der Struktur ihrer Formantenfrequenzen. Phonetica, 217-245.

Kamus Dewan (Edisi Keempat). (2005). Kuala Lumpur: Dewan Bahasa dan Pustaka.

Kent, R. D., \& Read, C. (2002). Acoustic Analysis of Speech (ed. 2nd). Albany, New York: Thomson Learning.

Ladefoged, P. (2001). A Course in Phonetics (ed. 4th). Texas: Harcourt College Publisher.

Ladefoged, P. (2001). Vowels and Consonant: An Introduction to the Sounds of Languages. Oxford: Blackwell.

Ladefoged, P. (2003). Phonetic Data Analysis: An Introduction to Instrumental Phonetic Fieldwork. Oxford: Blackwell.

Ladefoged, P., \& Ladefoged, J. (2003). German Vowels. Akses pada September, 2013, daripada UCLA Phonetics Lab Data: http://www.phonetics.ucla.edu/vowels/chapter14/ germ.html

Lado, R. (1964). Language Teaching: A Scientific Approach. New York: McGraw Hill, Inc.

Lex, B., \& Redecker, B. (2005). Phonetik auf einen Blick. H. Funk, C. Kuhn, \& S. Demme (Eds.), Studio D A1. Deutsch als Fremdsprache: Kurs-und Übungsbuch. (pp. 229-230). Berlin: Cornelsen Verlag.

Littlewood, W. (1984). Foreign and Second Language Learning. Language-acquisition Research and Its Implications for the Classroom. Cambridge: Cambridge University Press.

Mardian Shah Omar. (2005). Perbezaan Bunyi Vokal dan Konsonan: Satu Analisis Spektografik. Proceedings of the Seminar Kebangsaan Linguistik (SKALI 2005), (pp. 1-9). Bangi, Malaysia.

Marx, N., \& Mehlhorn, G. (2010). Pushing the positive: encouraging phonological transfer from L2 to L3. International Journal of Multilingualism, 7(1), 4-18.

Mayr, R., \& Escudero, P. (2010, July). Explaining Individual Variation In L2 Perception: Rounded Vowels In English Learners of German. Bilingualism: Language and Cognition, 13, 279-297.

Munro, J. (1993). Productions of English vowels by native speakers of Arabic: Acoustic measurements and accentedness ratings. Language and Speech, 39-66.

Rausch, R., \& Rausch, I. (2002). Deutsch für Ausländer. Berlin: Langenscheidt Verlag Enzyklopedie.

Roach, P. (2000). English Phonetics and Phonology (ed. 3rd). Cambridge: University Press. Roswati Abdul Rashid, Radhiah Ismail, \& Noor Haslina M. Akhir. (2007). Kepelbagaian Strategi Pembelajaran Tulisan Asas Bahasa Jepun (Hiragana): Satu Kajian Deskriptif. 3L Journal of Language Teaching, Linguistics and Literature, 13.

Russ, C. V. (2010). The Sounds of German. New York: Cambridge University Press.

Schunk, G. (2002). Studienbuch zur Einführung in die deutsche Sprachwissenschaft: Vom laut zum Wort. Würzburg: Verlag Königshausen \& Neumann GmbH. 
Selinker, L. (1972). Interlanguage. International Review of Applied Linguistics in Language Teaching, 209.

Selke, R. (2013). Post-PASCH Challenges in Teaching German Language in Malaysia. Studies on Foreign Language and Culture. 2, 70-94. Serdang: UPM Press.

Shaharina Mokhtar \& Shahidi A. Hamid. (2012). Analisis Akustik terhadap Forman Bunyi Vokal Bahasa Melayu: Satu Perbandingan antara Gender. Proceedings of the International Conference on Social Sciences \& Humanities, 301-313. Bangi, Malaysia.

Stefanie Pillai. (2014). The Monophthongs and Diphthongs of Malaysian English: An Instrumental Analysis. (Hajar Abdul Rahim, \& Shakila Abdul Manan (Eds.), English in Malaysia: Postcolonial and Beyond, 55-85.

Stefanie Pillai, Manueli, M. K., \& Dumanig, F. P. (2010). Monophthong vowels in Malaysian and Philippine English: An exploratory study. Philippine Journal of Linguistics, 41, 80-93.

Stefanie Pillai, Zuraidah Mohd Don, Knowles, G., \& Tang, J. (2010). Malaysian English: An Instrumental Analysis of Vowel Contrasts. World Englishes, 29(2), 159-172.

Tan, R., \& Low, E.-L. (2010). How different are the monophthongs of Malay speakers of Malaysian and Singapore English? English World-Wide, 31(2), 162-189.

Tomaschek, F., Wieling, M., Arnold, D., \& Baayen, H. (2013). Word Frequency, Vowel Length and Vowel Quality in Speech Production: An EMA Study of the Importance of Experience. 14th Annual Conference of the International Speech Communication Association. Lyon: Europa Organisation.

Watt, D., \& Tillotson, J. (2001). A Spectrografic Analysis of Vowel Fronting in Bradford English. English World-Wide, 22(2), 269-302.

Wrembel, M. (2014). VOT Patterns in the Acquisition of Third Language Phonology. International Symposium on the Acquisition of Second Language Speech (pp. 750770). Concordia Working Papers in Applied Linguistics.

Yap, N., Wong, B., \& Adi Yasran Abdul Aziz. (2010). Representation of English front vowels by Malay-English bilinguals. Pertanika Journal of Social Science and Humanities, 379-389.

Yunisrina Qismullah Yusuf. (2013). A Comparative Study of Vowels in the Acehnese Language Spoken in Kedah, Malaysia and Aceh, Indonesia (Unpublished doctoral dissertation). University of Malaya, Kuala Lumpur.

Yunus Maris. (1980). The Malay Sound System. Kuala Lumpur: Fajar Bakti.

Zwicker, E., \& Terhardt, T. (1980). Analitical Expression for Critical - Band Rate and Critical - Bandwidth as a Function of Frequency. Journal of the Acoustical Society of America, 68, 1523-1525.

Tarikh Peroleh (received): 31 Oktober 2019

Tarikh Terima (accepted): 21 Mac 2020 